Article

\title{
Experimental and Theoretical Investigations of a Modified Single-Slope Solar Still with an External Solar Water Heater
}

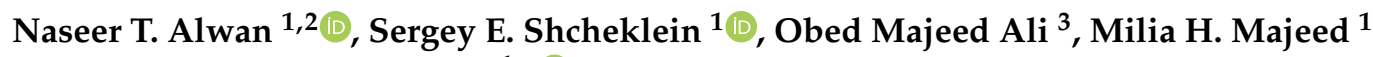

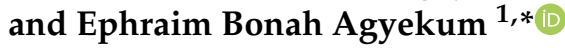 \\ 1 Department of Nuclear and Renewable Energy, Ural Federal University Named after the First President of \\ Russia Boris Yeltsin, 620002 Ekaterinburg, Russia; nassir.towfeek79@gmail.com (N.T.A.); \\ s.e.shcheklein@urfu.ru (S.E.S.); milia.hameed88@gmail.com (M.H.M.) \\ 2 Power Mechanics Department, Kirkuk Technical College, Northern Technical University, Kirkuk 36001, Iraq \\ 3 Renewable Energy Research Unit, Northern Technical University, Kirkuk 36001, Iraq; obedmajeed@ntu.edu.iq \\ * Correspondence: agyekumephraim@yahoo.com
}

\section{check for} updates

Citation: Alwan, N.T.; Shcheklein, S.E.; Ali, O.M.; Majeed, M.H.; Agyekum, E.B. Experimental and Theoretical Investigations of a Modified Single-Slope Solar Still with an External Solar Water Heater. Sustainability 2021, 13, 12414. https:/ / doi.org/10.3390/su132212414

Academic Editors: Maurice B.

Dusseault, SeyedBijan Mahbaz and Alireza Dehghani-Sanij

Received: 21 October 2021

Accepted: 8 November 2021

Published: 10 November 2021

Publisher's Note: MDPI stays neutral with regard to jurisdictional claims in published maps and institutional affiliations.

Copyright: (c) 2021 by the authors. Licensee MDPI, Basel, Switzerland. This article is an open access article distributed under the terms and conditions of the Creative Commons Attribution (CC BY) license (https:/ / creativecommons.org/licenses/by/ $4.0 /)$.

\begin{abstract}
One of the key impediments to the wide utilization of solar water desalination systems is limited production. Hence, this study aims at increasing the thermal performance of a single-slope solar still by increasing the surface area of evaporation and absorption exposed to sunlight. A hollow rotating cylinder was installed inside the still structure; this modified system was then joined with an outside solar water heater for productivity improvement. The obtained results show that a $0.5 \mathrm{rpm}$ rotational speed ensured that the cylinder's surface was kept wet. A mathematical model has been formulated using the finite difference method and the Fortran 90 programming language to assess the thermal performance productivity of two solar stills (conventional solar still (CSS) and modified solar still (MSS)) modelled under different conditions. The experimental and theoretical results are well agreed, with an error of $6.14 \%$. The obtained results show that the maximum productivity recorded in July 2019 was about $11.1 \mathrm{~L} / \mathrm{m}^{2}$ from the MSS and $2.8 \mathrm{~L} / \mathrm{m}^{2}$ from the CSS, with an improvement rate ranging between $286 \%$ and 300\% during June, July, August, and September 2019. The production cost per liter of distilled water from the modified and conventional solar stills was $0.0302 \mathrm{USD} / \mathrm{L}$ and $0.0312 \mathrm{USD} / \mathrm{L}$, respectively, which indicates a noticeable reduction in the cost of distillate water production.
\end{abstract}

Keywords: distillate water; single-slope solar still; solar water heater; hollow cylinder; water distillation

\section{Introduction}

The availability of drinking water is currently a major global issue due to the rapid depletion of freshwater resources. The United Nations Environment Program provided its report on the scarcity of drinking water between 1995 and 2025. By 2025, water scarcity is expected to increase significantly, according to the report [1]. Access to water in rural and remote areas is a major concern in most underdeveloped countries; this is worsened by the high level of water pollution due to industrial activities [2,3]. Therefore, access to fresh water is one of the biggest obstacles facing humans in remote and arid regions [4].

Providing water in such remote areas could save lives and reduce insurance as well as healthcare costs. Infrastructure investment in water treatment can provide freshwater supplies for homes and protect the livelihoods of low-income people in urban and rural communities [5]. Reports from the World Health Assembly indicate that over a million people lack drinking water, and the majority of such people live in remote and rural communities where freshwater units are usually difficult to construct [6].

The United Nations indicated in a report on an earlier study that many developing countries in the Middle East and North Africa suffer from freshwater scarcity as a result of the rapid growth of population in addition to the increasing activities in the industrial and agricultural sectors [7]. 
Potable water makes up $2.5 \%$ of the Earth's total water, even though the water coverage is about two-thirds of the Earth's surface. Seawater contains salinity levels ranging from 3500 to 4500 ppm; according to the World Health Organization data, the proportion of dissolved salt in drinking water should normally not be more than 500 ppm [8]. Hence, seawater cannot be employed directly for human utilization. However, many countries depend on desalinated seawater as a source of drinking water [9]. It is estimated that the world's average daily drinking-water production from the traditional desalination process is about $23 \times 10^{6} \mathrm{~m}^{3}$ [10]. Nevertheless, a lot of fossil fuel is consumed in the production process. Research has shown that about 130 million tons of oil is burnt every year to obtain 13 million cubic meters of drinkable water each day [11].

It has been reported that fossil fuel constitutes about $78.3 \%$ of the main source of energy globally, while renewable and nuclear energy constitute $19.2 \%$ and $2.5 \%$, respectively, as of 2016 [12-14]. For the above reasons, studies have been conducted on the use of renewable and clean sources of energy, such as the use of solar energy, which is considered as a sustainable, environmentally friendly viability for a different form of utilization $[15,16]$.

Several technologies have been used to produce freshwater using clean energy sources such as solar water distillation technology. Desalination technologies can be grouped into two: the membrane technologies, which include desalination by reverse osmosis (RO) and electrolysis for desalination (ED) [17], and the thermal technologies or phase change, which include multistage flash desalination [17], multi-effect boiling desalination [18], vapor compression desalination [19], freezing desalination [20], humidification and dehumidification desalination [21], and the integration of solar distillers with external solar collectors. A recently modified solar distiller has been investigated with an external solar heater. This study consisted of two stages. A hollow cylinder was combined with a single-slope solar distiller (modified solar still) in the first stage, and the modified solar distiller was combined with an external solar heater in the second stage. The hollow cylinder inside the solar distiller was spun at three rotational speeds: $0.5,1$, and $3 \mathrm{rpm}$. The results showed that $0.5 \mathrm{rpm}$ was the ideal rotational speed. When the modified solar distiller was combined with an outdoor solar heater, it boosted distillation water production by 292\% [22]. Another study investigated the integration of a vacuum tube solar heater with a solar distiller, both experimentally and theoretically, using Turkish climatic conditions. The study results revealed increased productivity from the improved distiller compared to the conventional solar distiller, and good agreement was observed between the mathematical model and the experimental data [23].

Another study improved the output of a conventional solar distiller by using a rotating cylinder inside the solar distiller. The results showed that the rate of improvement in water productivity at a rotational speed of $0.5 \mathrm{rpm}$ was about $161 \%$ compared with a conventional solar distiller [24].

Enhanced water distiller productivity was obtained by increasing the evaporation surface area and decreasing the saline water thickness by turning a traditional solar distiller into a modified solar distiller integrated with rotational discs. Eight rotational speeds were tested $(0.02,0.05,0.1,1,0.5,2,3$, and $4 \mathrm{rpm})$. The study results revealed greater daily water productivity for the modified model than the traditional solar distiller, and the best performance was with 0.05 and $0.1 \mathrm{rpm}$ with and without wick material. The improvement rate was $124 \%$ compared with a traditional solar distiller with rotational corrugated discs and a wick, while a maximum value of $54 \%$ and $50 \%$ for the thermal efficiency was obtained with a corrugated disc and a flat disc and a wick at $0.05 \mathrm{rpm}$, respectively [25].

Abdullah et al. [26] examined the effectiveness of a solar still augmented with a rotating wick and a PV solar panel and revealed a lower production cost for one liter of distilled water than that from a traditional solar still by $47 \%$.

An experimental study was conducted in Moradabad by integrating a solar water collector (SWC) and a solar dish cooker to improve the distilled water production. The results from the study showed that the daily yield was 3.66 each day. Using the combined unit for $3 \mathrm{~h}$ per day produced $1.15 \mathrm{~L}$ of fresh water in conjunction with heating water and 
cooking with solar energy, according to the environmental conditions [27]. A new study was conducted that involved increasing the rate of evaporation inside the solar distiller by installing a hollow rotating cylinder inside it.

Ayoub et al. [28] suggested a new technical variation to enhance the output of a solar distiller. This consists of an easy modification to the slowly revolving hollow cylinder placed within the solar distiller, which enables it to produce thin water films on its surface, enabling it to rapidly evaporate and be continuously regenerated. Results from their study suggest an improvement of over $200 \%$ in the productivity. The study concluded that through this improvement, various parameters, such as low cost, space conservation, material availability, efficiency, simplicity of management, and safe water quality, are met.

Malaeb et al. [29] modified solar distillation by using a rotating cylinder. A theoretical idea was advanced based on mass and heat balance equations. The constructed model was used to learn about the effects of essential parameters. Three experimental correlations were involved for the heat transfer coefficient's calculations. For each case, error analysis was provided. They found that the cylinder speed was inversely proportional to the distillation of water. The rotation varied between 0.25 and $4 \mathrm{rpm}$. They identified that the limiting speed should change depending on the specific climate conditions from 0.25 to $0.5 \mathrm{rpm}$. The results revealed that the suggested amendment supports solar still desalination significantly and allows for the implementation of this technology.

Ayoub and Malaeb [30] conducted a study to evaluate the economic and operational properties of solar distillates. The outcome of their study indicated that a modified solar distiller increased the daily yield by 200-300\%. A lower production cost per litre of distilled water was also observed compared to other types of distillation devices. Hitesh et al. [31] conducted an experimental study to show the effect of increasing the surface area of a solar still basin by adding vertical and inclined fins. The researchers used three solar stills, the first without any improvements, the second and the third with improvements (fins). The results showed that the average yield of the three solar stills (inclined fins, vertical fins, and the conventional solar still) are as follows: $2.375,2.322$, and 1.873, respectively, with an improvement ratio of about $26.7 \%$, and $24.1 \%$, respectively. In another study, Hitesh et al. [32] proposed a multi-effect (dual-basin) solar still with vacuum tubes. The water basin was provided with two types of fins, solid and mild steel. Two solar stills were used, one of them was conventional, with vacuum tubes, and the other was an improved type with fins, in addition to the vacuum tube machine. The results showed that there was an improvement in the productivity of the modified solar still by $25 \%$ over that of the conventional solar still. Hitesh et al. [33] pointed out the importance of integrating a solar pond in raising the temperature of the basin water in the solar still water in a detailed study. The researchers concluded that the integration of the solar pond with the solar still increases the daily yield at different rates.

The rate of water evaporation increases as the depth decreases [34]. Based on this principle, a modified solar distiller was integrated with a hollow rotating cylinder open at both sides, which were lightweight and fixed on a rotating shaft. The lower side of the hollow cylinder was immersed in $1 \mathrm{~cm}$ of water and coated with black paint to increase its capacity to absorb solar energy. A thin water film formed over the hollow cylinder circumference when it rotated and was constantly renewed with every turn of the cylinder. This water film rapidly evaporated from the hot, hollow cylinder surface [22] due to the rapidity with which heat was transferred from the hollow cylinder surface to the thin water film. Conventional solar stills take longer to heat up and evaporate the basin water.

Water film evaporation from the surface of a hollow cylinder depends on its rotation speed, so it must be appropriate (not too fast or too slow). The water film layer does not evaporate entirely when it is too fast; moreover, the surface of the cylinder dries quickly as a result of the rapid evaporation of the water film layer if it is too slow. Four rotational speeds, 0.5, 1, 3, and $6 \mathrm{rpm}$, were tested by Alwan et al. [22]. The results showed that the perfect speed was $0.5 \mathrm{rpm}$ because this rotational speed obtained the highest productivity and the best thermal performance. The water film on the surface of the cylinder had enough 
time to evaporate for the other rotational speeds, the evaporation time decreased as the speed increased.

To overcome the problem of low water temperature in the basin due to the shadow of the hollow cylinder (which covers $76 \%$ of the area of the basin water surface), a modified solar distiller was integrated with an outdoor solar collector [22].

Many studies, as reviewed above, have been conducted to improve solar distillate yield as well as to decrease the cost associated with production. Most of these studies adopted experimental procedures to evaluate the performance of a modified solar distiller due to the difficulties of implementing theoretical models, which must deal with complicated designs and a large variety of environmental conditions. Hence, the current work aims to investigate numerically and experimentally the effect of the solar water distiller modifications in different environmental and operational conditions on thermal performance and the production rate of distilled water. The study focuses on improving the productivity of modified solar distillers at a lower cost and evaluating the performance of the suggested modified design in different climate conditions. The Fortran 90 programming language is used to mathematically model a solar water distiller.

\section{Materials and Methods}

\subsection{Test Rig Configuration}

Figures 1 and 2 illustrate the photographic and schematic diagram for the experimental setup of the two models of solar still in the current study: the conventional solar still (CSS) and the modified solar still (MSS). To compare the thermal performance of the two models, identical dimensions and operating conditions have been used.

The solar distiller's surface area was $0.5 \mathrm{~m}^{2}$, while its wooden structure was $103.6 \mathrm{~cm}$ long, $53.6 \mathrm{~cm}$ wide, $61.8 \mathrm{~cm}$ high (big side), $26.6 \mathrm{~cm}$ high (small side), and $1.8 \mathrm{~cm}$ thick. An MDF board of $100 \mathrm{~cm}$ in width, $60 \mathrm{~cm}$ in height, and $1.8 \mathrm{~cm}$ thick was fixed onto the back of the solar distiller. The structure of the solar distiller consisted of three parts: a plexiglass cover, a frame, and a base made of wood. The plexiglass cover was $100 \mathrm{~cm}$ in length, $50 \mathrm{~cm}$ in width, $50 \mathrm{~cm}$ high (big side), $14.8 \mathrm{~cm}$ high (small side), and $0.3 \mathrm{~cm}$ thick; it was positioned at the top of the solar distiller at an angle of $35^{\circ}$. An aluminium channel was used to fix the plexiglass cover to the wooden frame to gather the distilled water in a plastic bottle at the bottom of the solar distiller. The solar distiller's base was $103.6 \mathrm{~cm}$ in length, $53.6 \mathrm{~cm}$ in width, and $1.8 \mathrm{~cm}$ thick. The solar distiller's inner surface was covered with $0.03 \mathrm{~cm}$ of aluminium foil; this was intended to enhance productivity by reflecting solar radiation onto the internal surfaces of the solar still. In order to prevent the leakage of air, silicone glue was used to fix all the parts of the system together. The basin was made with a stainless-steel plate $100 \mathrm{~cm}$ long, $50 \mathrm{~cm}$ wide, $10 \mathrm{~cm}$ high, and $0.1 \mathrm{~cm}$ thick. To increase the basin-metal capacity for solar radiation absorption, it was coated with black paint. A hollow cylinder with a diameter of $32 \mathrm{~cm}$, a thickness of $0.1 \mathrm{~cm}$, and a length of $90 \mathrm{~cm}$, with a stainless-steel plate of length $100 \mathrm{~cm}$ and $100 \mathrm{~cm}$ in width, was coated with black paint to increase its capacity to absorb solar energy. The hollow cylinder was installed inside the modified solar distiller with a shaft made of low carbon steel, $0.8 \mathrm{~cm}$ in diameter, and $95 \mathrm{~cm}$ in length; on the two ends of the shaft were mounted two bearings of $0.8 \mathrm{~cm}$ in diameter. A DC motor was installed with a PWM speed regulator switch circuit consisting of a variable resistance volume switch which makes available the required voltage and current to drive the DC motor. A charge controller battery with a capacity of $110 \mathrm{~W}$ was used to power the circuit as well as a photovoltaic solar panel. The DC motor rotated the hollow cylinder with a V-belt, which consumed (12 V) and (0.1 A) and has (6.8 N.m). A $50 \mathrm{~cm}$ diameter water tank with a height of $100 \mathrm{~cm}$ was used to supply water to the solar distillers through insulated rubber tubes. A mechanical floater was used to keep the water level at $5 \mathrm{~cm}$ in the basin. In order to clean impurities and salts from the basin, a hole of $1.27 \mathrm{~cm}$ in diameter with a globe valve was drilled at the base of the water tank.

The modified solar distiller was integrated into the external SWC by [22], which was made from a wooden frame with a length of $120 \mathrm{~cm}$, a width of $110 \mathrm{~cm}$, and a height 
of $10 \mathrm{~cm}$, with a surface area of $13,200 \mathrm{~cm}^{2}$. The modified solar distiller isolated all its elements and covered them with a stainless-steel absorbent plate from the bottom, painted dull black so that it could rapidly absorb heat and quickly transfer the heat to the attached tubes (dimensions of the absorber plate: $110 \mathrm{~cm} \times 90 \mathrm{~cm} \times 0.1 \mathrm{~cm}$, with a $9900 \mathrm{~cm}^{2}$ surface area). Thirty tubes of copper were placed on the black steel plate with the inside and outside diameters of $1.6 \mathrm{~cm}$ and $1.7 \mathrm{~cm}$ for each tube and a $2 \mathrm{~cm}$ space between each pipe. The water circulated through the header, which was made of copper and had a diameter of $2.8 \mathrm{~cm}$, and through the copper tubes. The inlet and outlet headers were made from copper with diameters of $2.8 \mathrm{~cm}$ and $4.2 \mathrm{~cm}$, respectively. The top flat plate was covered with clear glass and the solar water collector (dimensions: $116 \mathrm{~cm} \times 106 \mathrm{~cm} \times 0.04 \mathrm{~cm}$ ). This allowed the sun's rays to enter while minimizing absorber plate heat losses. The solar collector was inclined 35 degrees; this is because the sun's rays in summer, especially in June and July, are almost perpendicular to the surface of the earth, so in order to be suitable for the rest of the months, an angle of 35 degrees was chosen to be suitable for most seasons of the year. This was implemented after several tests. A water pump with $12 \mathrm{~V} \mathrm{DC}, 0.66 \mathrm{~A}$, and $1.2 \mathrm{~L} / \mathrm{min}$ volumetric flow rate was adopted to circulate the system.

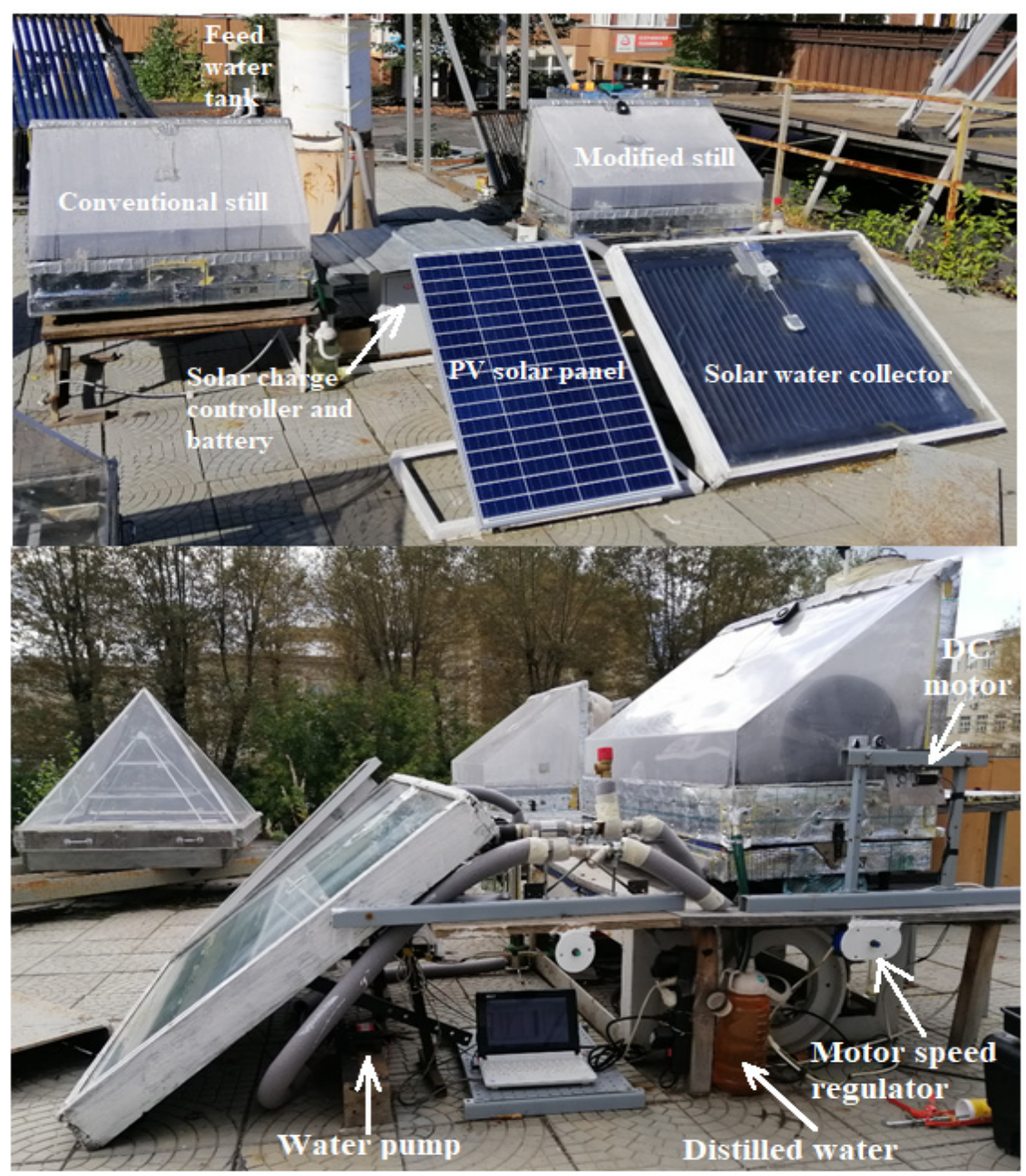

Figure 1. A photograph of the modified solar still and a conventional solar still. 


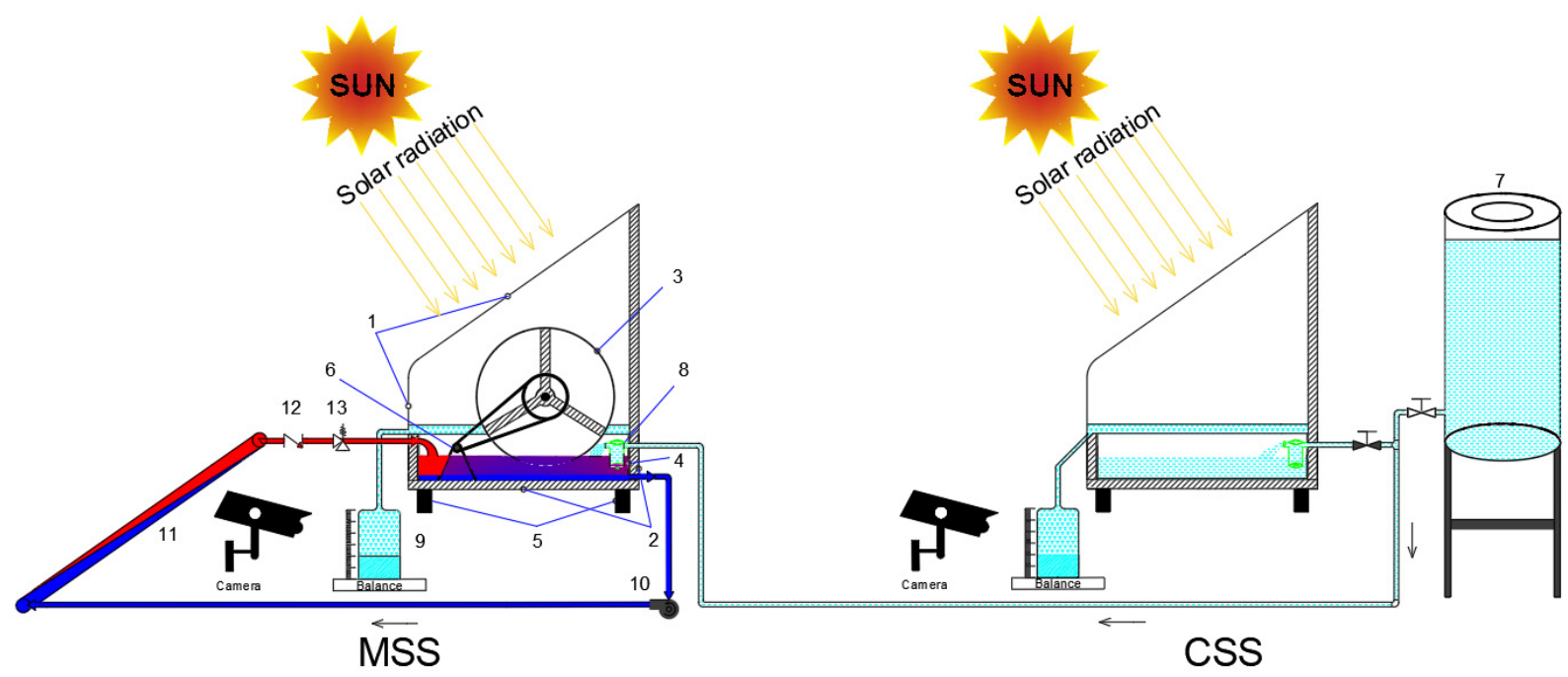

Figure 2. Schematic diagram of the experimental system (CSS and MSS): (1) plexiglass cover; (2) MDF board; (3) rotating hollow cylinder; (4) water basin; (5) base; (6) 12V-DC motor; (7) feed water tank; (8) mechanical floater; (9) purified water tank; (10) water pump; (11) solar water collector; (12) check valve; (13) safety valve [22].

\subsection{Experimental Procedure}

This research was conducted at Ural Federal University from the months of June to September, starting from 08:00 a.m. and ending at 8:00 p.m. for each experimental day. The system was directed to the south according to the climate conditions of Ekaterinburg, Russia, and the data were collected during four chosen typical days. The sunrise and sunset times for June, July, August, and September 2019 were 04:10 a.m. and 9:50 p.m.; 04:20 a.m. and 9:40 p.m.; 05:20 a.m. and 8:40 p.m.; and 06:20 a.m. and 7:20 p.m., respectively. The mass of the water in the basin was $21.5 \mathrm{~kg}$, and this weight was appropriate for the height of the basin water at approximately $5 \mathrm{~cm}$.

The following steps were conducted for each experimental session:

(a) cleaned the plexiglass cover of the solar distiller of dirt and dust;

(b) opened the water supply valve to fill the basin with water until it reached a level of $5 \mathrm{~cm}$ through a mechanical floater;

(c) the hollow rotating cylinder DC motor was started and was regulated at $0.5 \mathrm{rpm}$ through the speed regulator;

(d) turned on the DC water pump to circulate the water between the modified solar distiller and the flat solar collector. The water flow rate was fixed at $1.2 \mathrm{~L} / \mathrm{min}$ by the flow meter.

\subsection{Instruments and Uncertainty Analysis}

Many instruments were used to record the results of the effect of the investigated parameters on the solar water still's thermal performance, such as a k-type SD data logger with 4 channel modules (88598), which collected the temperature within different points of the solar still, including the basin plate $\left(T_{p}\right)$, the basin water $\left(T_{w}\right)$, the hollow cylinder's inner surface $\left(T_{h c i}\right)$, the hollow cylinder's outer surface $\left(T_{h c o}\right)$, the plexiglass cover's inner surface $\left(T_{g i}\right)$, and the plexiglass cover's outer surface $\left(T_{g o}\right)$. The ambient air temperature and the intensity of the solar radiation were measured using a GM $1362 \mathrm{~m}$ and a solar power meter device (TENMARS TM-207), respectively. The ambient wind speed was also measured using an anemometer (ut363), as illustrated in Figure 3. 


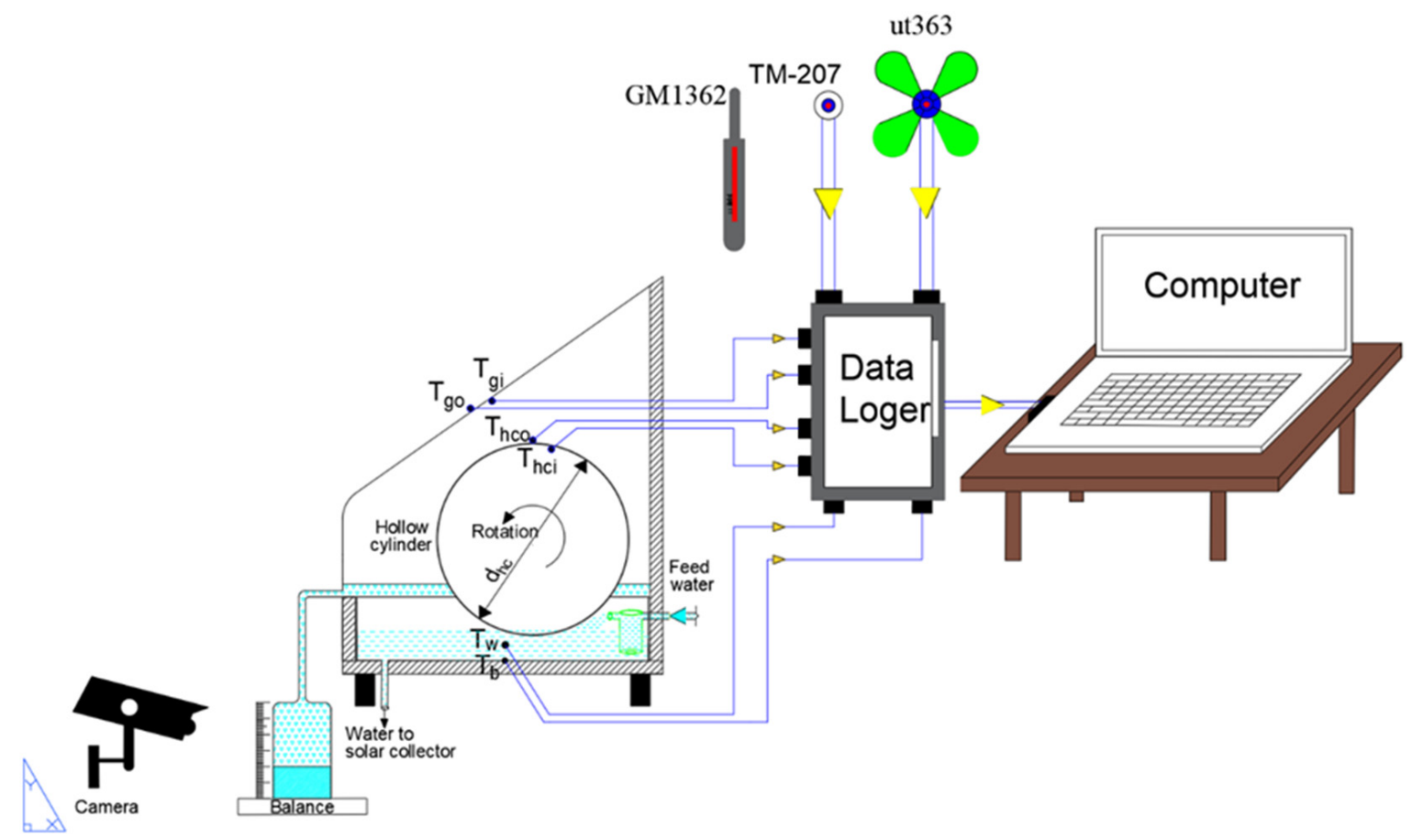

Figure 3. A schematic diagram of the measuring devices.

In an experimental study, uncertainty analysis is a necessary step to give confidence in the results. It is essential to assess the range of the measuring error ratio for each measuring device and the value of accuracy to calculate the uncertainty of the experimental measurements, as shown in Table 1, which have been calculated based on the following equations [35-37]:

$$
\begin{gathered}
S=\sqrt{\frac{\sum_{i=1}^{n}\left(X_{i}=X^{\prime}\right)^{2}}{n-1}} \\
S . E=\frac{S}{\sqrt{n}} \\
\text { Error ratio }=\frac{S . E}{X^{\prime}} \times 100 \% \\
X^{\prime}=\frac{\sum_{i=1}^{n} X_{i}}{n}
\end{gathered}
$$

where the standard error (SE) has been calculated based on the standard deviation $(S)$, and the measured value $\left(X_{i}\right)$ is a measurement value, in addition to the mean measurement value $\left(X^{\prime}\right)$ for $n$ number of measurements.

Table 1. Device accuracy and measurement error range.

\begin{tabular}{ccc}
\hline Equipment/Unit & Accuracy/Range & \% Error \\
\hline Thermometer $/{ }^{\circ} \mathrm{C}$ & $1^{\circ} \mathrm{C} / 1-100$ & $0.5 \%$ \\
\hline Thermocouple $/{ }^{\circ} \mathrm{C}$ & $0.1^{\circ} \mathrm{C} /-100-200$ & $0.3 \%$ \\
\hline Data logger $/{ }^{\circ} \mathrm{C}$ & $1{ }^{\circ} \mathrm{C} /-200-1370$ & $0.3 \%$ \\
\hline Solar meter $/ \mathrm{W} / \mathrm{m}^{2}$ & $0.1 \% / 0-2000$ & $0.1 \%$ \\
\hline Anemometer $/ \mathrm{m} / \mathrm{s}$ & $0.2 / 0-20$ & $2.5 \%$ \\
\hline
\end{tabular}




\section{Theoretical Analysis}

The transfer of heat within the solar still is simulated based on the evaporation and condensation principles in order to investigate the parameters that influence their performance and productivity. The equation of the energy balance within the investigated modified solar still is illustrated in Figure 3, which mainly includes the conduction, convection, radiation, and evaporation. The following assumptions have been adopted to describe the solar still thermal behavior: (a) there is an optimal slope of the glass cover without leakage of air within the solar still; (b) there is no dirt or dust on the plexiglass cover; (c) there is perfect installation and pipe connection of the solar water distillery; (d) an energy balance between the surface of the rotating hollow cylinder and the adjacent water film is assumed; (e) there is uniform thickness of water film along the elemental strip; (f) there is uniform temperature along each elemental strip; and (g) the dry air and water vapor behave like an ideal gas [35].

\subsection{Conventional Solar Distiller}

The details of the heat balance of a conventional solar distiller, including the basin liner (bp), basin water (w), and plexiglass cover $(\mathrm{Pg})$, were explained in [34].

\subsection{Combined Modified Solar Still}

\subsubsection{Basin Water Liner (b)}

The thermal balance of the rate of the absorbed energy and stored energy by the basin water plate can be represented as follows [38]:

$$
I(t) \times\left(A_{b}-A_{s}\right) \times \alpha_{b} \times \tau_{P g} \times \tau_{w}=m_{b} \times C p_{b} \cdot \frac{d T_{b}}{d t}+Q_{C, b-w}+Q_{\text {Loss, } b-a}
$$

where the thermal absorbed energy and stored energy are equal and $I(t)$ denotes the intensity of solar radiation $\mathrm{W} / \mathrm{m}^{2}, A_{b}$ denotes the surface area of the basin $\left(\mathrm{m}^{2}\right), A_{s}$ represents the hollow cylinder's shadow area $\left(\mathrm{m}^{2}\right), T_{w}$ is the basin water temperature $\left({ }^{\circ} \mathrm{C}\right), \alpha_{b}$ is the absorptivity of the basin plate, $\tau_{P g}$ is the transmittance of plexiglass, $\tau_{w}$ is the transmittance of the water, $m_{b}$ is the basin plate mass $(\mathrm{Kg}), C p_{b}$ is the specific heat of the basin plate (J/kg.K), $Q_{C, b-w}$ is the convection heat transfer from the basin liner to the basin water $(\mathrm{W})$, and $Q_{\text {Loss, } b-a}$ signifies the heat transfer (energy loss) from the basin liner to the ambient air $(\mathrm{W})[38]$.

$$
\begin{aligned}
& Q_{C, b-w}=h_{c, b-w} \times A_{b} \times\left(T_{b}-T_{w}\right) \\
& Q_{\text {Loss }, b-a}=h_{b, b-a} \times A_{b} \times\left(T_{b}-T_{a}\right)
\end{aligned}
$$

where $h_{c, b-w}$ represents the coefficient of heat transfer by convection from the basin liner to the basin water $\left(\mathrm{W} / \mathrm{m}^{2} . \mathrm{K}\right), T_{b}$ is the basin liner temperature $\left({ }^{\circ} \mathrm{C}\right), T_{w}$ is the basin water temperature $\left({ }^{\circ} \mathrm{C}\right), h_{b_{b}-a}$ denotes the overall coefficient of heat transfer from the bottom basin liner to the ambient air $\left(\mathrm{W} / \mathrm{m}^{2} . \mathrm{K}\right)$, and $T_{a}$ is the ambient air temperature $\left({ }^{\circ} \mathrm{C}\right)$.

Convection heat transfer from the basin liner to the basin water is obtained as follows [38]:

$$
h_{c, b-w}=\frac{\overline{N u_{L}} \cdot K_{w}}{L_{b}}
$$

where

$$
\left\{\begin{array}{cc}
N u_{L}=0.54 R a_{L}^{\frac{1}{4}} & \left(10^{4} \leq R a_{L} \leq 10^{7}\right) \\
N u_{L}=0.15 R a_{L}^{\frac{1}{3}} & \left(10^{7} \leq R a_{L} \leq 10^{11}\right)
\end{array}\right\}
$$


$K_{w}$ is the water thermal conductivity $(\mathrm{W} / \mathrm{m} . \mathrm{K}), L_{b}$ is the ratio of the surface area to the perimeter of the basin plate $(\mathrm{m})$, and $R_{a}$ is the Rayleigh number:

$$
R_{a}=\frac{g \times \beta_{w} \times L_{b}^{3} \times\left(T_{b}-T_{w}\right)}{v_{w} \times \alpha_{w}}
$$

where $v_{w}$ is the kinematic viscosity $\left(\mathrm{m}^{2} / \mathrm{s}\right), \alpha_{w}$ is the thermal diffusivity $\left(\frac{\mathrm{m}^{2}}{\mathrm{~s}}\right)$, and $\beta_{w}$ is the basin water thermal expansion coefficient: $\left[\alpha_{w}=\frac{k_{w}}{\rho_{w v} \cdot c p_{w}}\right.$ and $\left.\beta_{w}=\frac{1}{T}\left(\frac{1}{R}\right)\right]$.

The coefficient of heat transfer from the bottom basin liner to the ambient air can be computed using the following relations:

$$
h_{b_{b}-a}=\left[\frac{L_{i}}{K_{i}}+\frac{1}{h_{t, b-a}}\right]^{-1}
$$

where the insulation thickness is denoted by $L_{i}(0.18 \mathrm{~cm}), K_{i}$ denotes the insulation thermal conductivity $(\mathrm{W} / \mathrm{m} . \mathrm{k})$. The total heat transfer coefficient (convection and radiation) from the basin liner to the ambient air $\left(h_{t, b-a}\right)\left(\mathrm{W} / \mathrm{m}^{2} . \mathrm{k}\right)$ is expressed as follows [38]:

$$
h_{t, b-a}=5.7+3.8 \times V_{a}
$$

where $V_{a}$ is the ambient airspeed $(\mathrm{m} / \mathrm{s})$. The heat and mass transfer for the modified solar distiller is illustrated in Figure 4.

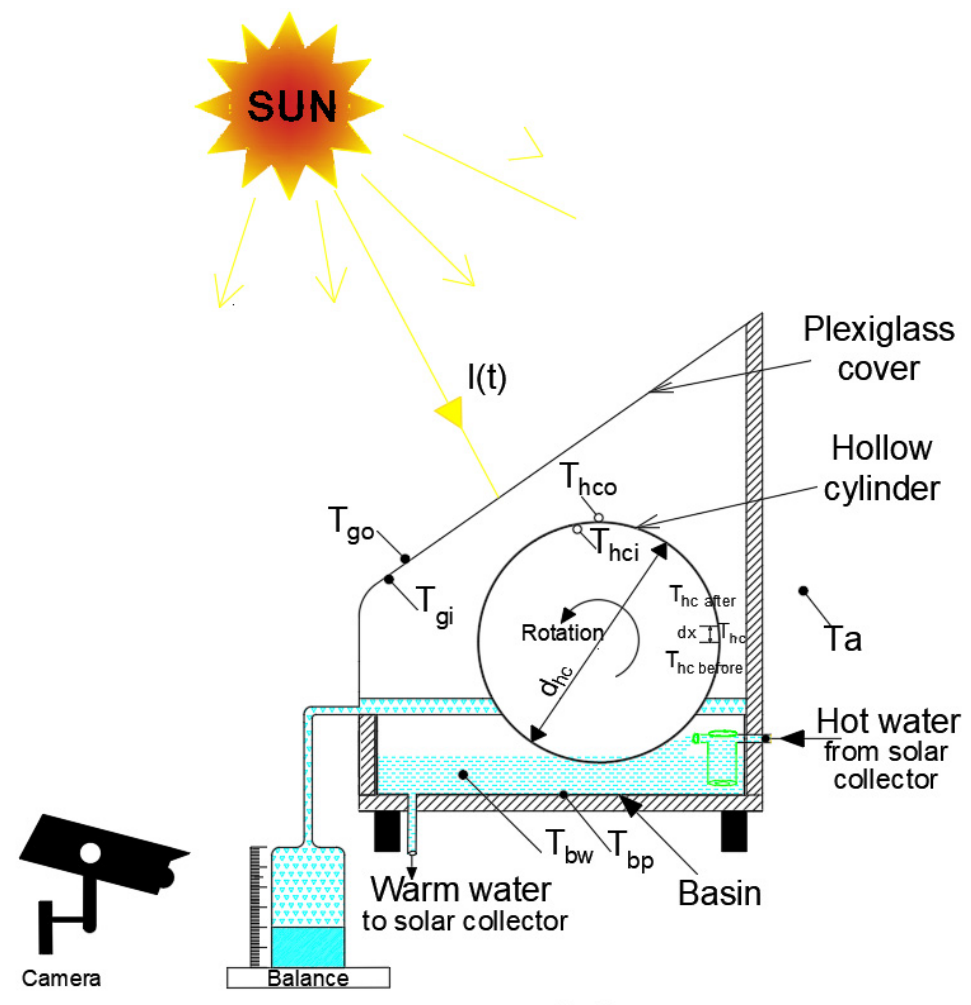

MSS

Figure 4. Heat and mass transfer in a modified solar distiller.

\subsubsection{The Rotating Hollow Cylinder $\left(h_{c}\right)$}

The transient heat transfer between the hollow cylinder's surface and the wet air around the inner and outer surfaces of the hollow cylinder is obtained as follows: 
$I(t) \times \alpha_{h c} \times\left(1-\alpha_{p g}\right)=\frac{d}{d t}\left[m_{h c} \times C_{p h c} \times T_{h c}+m_{f w} \times C_{p f w} \times T_{f w}\right]+Q_{c o n d-h c}+Q_{t, h c o-P g i}+Q_{t, h c i-P g i}$

where

$$
\begin{gathered}
Q_{c o n d-h c}=k_{h c}\left(\frac{T_{h c}-T_{h c-h c, b e f o r e}}{t h x_{h c}}\right)+k_{h c}\left(\frac{T_{h c-h c, \text { after }}-T_{h c}}{t h x_{h c}}\right) \\
Q_{t, h c o-g i}=\left[h_{c, h c o-P g i}+h_{r, h c o-P g i}+h_{e, h c o-P g i}\right]\left(T_{h c o}-T_{P g i}\right) \\
Q_{t, h c i-P g i}=\left[h_{c, h c i-P g i}+h_{c, h c i-P g i}\right]\left(T_{h c i}-T_{P g i}\right)
\end{gathered}
$$

$\alpha_{h c}$ is the absorptivity of the hollow cylinder plate, $\alpha_{g}$ is the absorptivity of the plexiglass cover, $m_{h c}$ is the hollow cylinder element mass $\left(\mathrm{kg} / \mathrm{m}^{2}\right)$ for a specified period $\mathrm{dt}(\mathrm{s})$, $m_{f w}$ is the water film mass and the hollow cylinder $\left(\mathrm{kg} / \mathrm{m}^{2}\right), C_{P h c}$ is the hollow cylinder's specific heat $(\mathrm{J} / \mathrm{kg} . \mathrm{K}), C_{P f w}$ is the water film's specific heat $(\mathrm{J} / \mathrm{kg} . \mathrm{K}), T_{h c}$ is the hollow cylinder's temperature $\left({ }^{\circ} \mathrm{C}\right), T_{f w}$ is the water film's temperature $\left({ }^{\circ} \mathrm{C}\right), T_{f w}=T_{h c}$ is assumed, $Q_{\text {cond-hc }}$ is heat transfer by conduction through the plate of the hollow cylinder $(\mathrm{W})$, $Q_{t, h c o-P g i}$ is the total heat transfer from the outer surface of the hollow cylinder to the inner surface of the plexiglass cover $(\mathrm{W}), Q_{t, h c i-P g i}$ is the total heat transfer from the inner surface of the hollow cylinder to the outer surface of the plexiglass cover $(\mathrm{W}), k_{h c}$ is the hollow cylinder plate's thermal conductivity $(\mathrm{W} / \mathrm{m} . \mathrm{k}), t h x_{h c}$ is the hollow cylinder's thickness $(1 \mathrm{~mm}), T_{h c \text {,before }}$ and $\mathrm{T}_{h c, \text { after }}$ are the temperatures of the two longitudinal elements of the hollow cylinder (these elements are directly connected to the element under consideration, as shown in Figure 5), $h_{C, h c o-P g i}$ is the coefficient of heat transfer by convection between the outer hollow cylinder and the inner surface of the plexiglass cover $\left(\mathrm{W} / \mathrm{m}^{2} . \mathrm{k}\right), h_{r, h c o-P g i}$ is the coefficient of heat transfer by radiation between the outer hollow cylinder and the inner surface of the plexiglass cover $\left(\mathrm{W} / \mathrm{m}^{2} . \mathrm{k}\right), h_{e, h c o-P g i}$ is the coefficient of heat transfer by evaporation between the inner surface of the plexiglass cover and the outer hollow cylinder $\left(\mathrm{W} / \mathrm{m}^{2} . \mathrm{k}\right), T_{h c o}$ is the temperature of the outer surface of the hollow cylinder $\left({ }^{\circ} \mathrm{C}\right)$, $T_{h c i}$ signifies the outer surface temperature of the hollow cylinder $\left({ }^{\circ} \mathrm{C}\right)$, and $T_{P g i}$ is the temperature of the inner surface of the plexiglass $\left({ }^{\circ} \mathrm{C}\right)$.

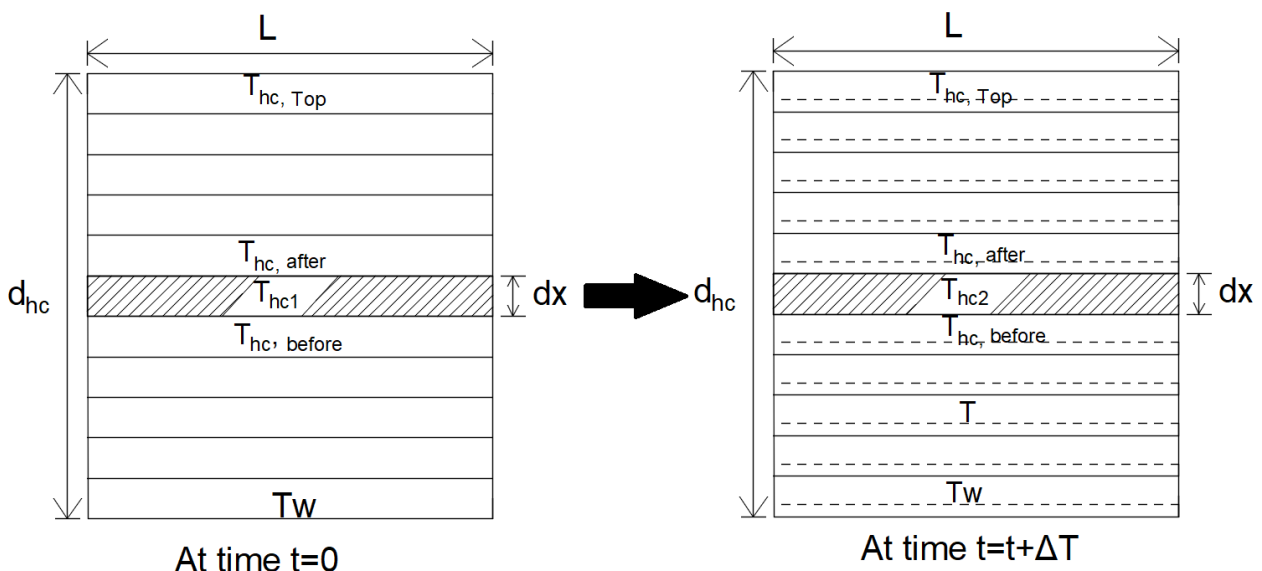

Figure 5. Evolution of the longitudinal elements of a rotating hollow cylinder over time.

The convection heat transfer coefficient between the outside of the hollow cylinder and the inner plexiglass cover is given as follows [38]:

$$
h_{C, h c o-P g i}=0.884 \times\left(\Delta T^{\prime}\right)^{1 / 3}
$$




$$
\Delta T^{\prime}=\left(T_{h c o}-T_{P g i}\right)+\frac{\left(P_{h c o}-P_{P g i}\right) \times\left(T_{h c o}+273.15\right)}{\left(26.89 \times 10^{4}-P_{h c o}\right)}
$$

where $P_{h c o}$ is the vapor pressure on the temperature of the outer surface of the hollow cylinder and $P_{p g i}$ is the vapor pressure on the inner plexiglass cover's temperature [38]:

$$
\begin{gathered}
P_{h c o}=\exp \left(25.317-\frac{5144}{T_{h c o}+273.15}\right) \\
P_{g i}=\exp \left(25.317-\frac{5144}{T_{p g i+273.15}}\right)
\end{gathered}
$$

The evaporation heat transfer coefficient between the outside of the hollow cylinder and the inside surface of the plexiglass cover is given as follows [38]:

$$
h_{e, h c o-g i}=16.273 \times 10^{-3} h_{c, h c o-p g i} \times \frac{\left(P_{h c o}-P_{P g i}\right)}{\left(T_{h c o}-T_{P g i}\right)}
$$

The radiation heat transfer coefficient between the outside elements of the hollow cylinder and the inside surface of the plexiglass cover is given as follows [39]:

$$
h_{r, h c o-P g i}=\varepsilon_{e f f} \sigma\left[\left(T_{h c o}+273.15\right)^{2}-\left(T_{P g i}+273.15\right)^{2}\right] \times\left[T_{h c o}+T_{P g}+546\right]
$$

$\varepsilon_{e f f}$ is the effective emissivity of the water surface to the plexiglass cover:

$$
\varepsilon_{e f f}=\frac{1}{\left(\frac{1}{\varepsilon_{h c o}}+\frac{1}{\varepsilon_{P g i}}-1\right)}
$$

where $\sigma$ is the Boltzmann constant (taken as $5.67 \times 10^{-8} \mathrm{~W} / \mathrm{m}^{2} \mathrm{k}^{4}$ ), $\varepsilon_{\text {hco }}$ denotes the emittance of the outside of the hollow cylinder, and $\varepsilon_{g i}$ is the emittance of the plexiglass cover.

The convection heat transfer coefficient between the inside surface of the plexiglass cover and the inside of the hollow cylinder is as follows [38]:

$$
\begin{gathered}
h_{C, h c i-g i}=0.884 \times\left(\Delta T^{\prime}\right)^{1 / 3} \\
\Delta T^{\prime}=\left(T_{h c i}-T_{P g i}\right)+\frac{\left(P_{h c i}-P_{P g i}\right) \times\left(T_{h c i}+273.15\right)}{\left(26.89 \times 10^{4}-P_{h c i}\right)}
\end{gathered}
$$

where $P_{h c i}$ is the vapor pressure on the temperature of the hollow cylinder's inner surface [38]:

$$
P_{h c i}=\exp \left(25.317-\frac{5144}{T_{h c i}+273.15}\right)
$$

The evaporation heat transfer coefficient between the inner plexiglass cover and the inside of the hollow cylinder is as follows [38]:

$$
h_{e, h c i-g i}=16.276 \times 10^{-3} h_{c, h c i-P g i} \times \frac{\left(P_{h c i}-P_{P g i}\right)}{\left(T_{h c i}-T_{P g i}\right)}
$$

\subsubsection{Basin Water $(w)$}

The rate of absorbed solar energy by the basin plate, the rate of the heat transfer by convection from the basin plate to the basin water $Q_{c, b-w}(\mathrm{~W})$, and the useful heat gained from the flat plate solar collector $Q_{u}(\mathrm{~W})$ are equal to the rate of thermal energy stored 
and the total thermal energy transferred $Q_{t, w-P g i}$ by convection $Q_{c, w-P g i}(\mathrm{~W})$, evaporation $Q_{e, w-g i}(\mathrm{~W})$, and radiation $Q_{r, w-P g i}(\mathrm{~W})$ to the inner surface of the plexiglass cover:

$$
\begin{gathered}
Q_{u}+I(t) \times\left(A_{b}-A_{s}\right) \times \alpha_{w} \times \tau_{P g}+Q_{c, b-w}=m_{w} \mathcal{c}_{w}\left(\frac{d t_{w}}{d t}\right)+Q_{t, w-P g i} \\
Q_{t, w-P g i}=Q_{c, w-P g i}+Q_{r, w-P g i}+Q_{e, w-g i} \\
Q_{u}+I(t) \times\left(A_{b}-A_{s}\right) \times \alpha_{w} \times\left(1-\alpha_{P g}\right)+h_{c, b-w} \times A_{b} \times\left(T_{b}-T_{w}\right) \\
=m_{w} \times C p_{w} \times\left(\frac{d t_{w}}{d t}\right)+\left[h_{c, w-P g i}+h_{e, w-P g i}+h_{r, w-P g i}\right] \times\left(A_{b}-A_{s u}\right) \times\left(T_{w}-T_{P g i}\right)
\end{gathered}
$$

where the basin water surface area is denoted by $A_{w} \cdot m^{2}, \alpha_{w}$ signifies the absorptivity of the basin water, $m_{w}$ is the mass of the basin water $\mathrm{kg}, C_{P w}$ is the heat capacity of the basin water $\mathrm{J} / \mathrm{kg} .{ }^{\circ} \mathrm{C}, h_{c, w-P g i}$ is the coefficient of heat transfer by convection from the basin water to the inner surface of the plexiglass cover $\left(\mathrm{W} / \mathrm{m}^{2} . \mathrm{k}\right), h_{e, w-P g i}$ is the coefficient of heat transfer by evaporation from the basin water to the inner surface of the plexiglass cover $\left(\mathrm{W} / \mathrm{m}^{2} . \mathrm{k}\right), h_{r, w-P g i}$ is the coefficient of heat transfer by radiation from the basin water to the inner surface of the plexiglass cover $\left(\mathrm{W} / \mathrm{m}^{2} . \mathrm{k}\right)$, and $A_{s u}$ is the submerged area of the hollow cylinder in the basin water $\left(\mathrm{m}^{2}\right)$.

The coefficient of heat transfer by convection from the basin water to the inner surface of the plexiglass cover is derived according to Dunkel's relation [38]:

$$
\begin{gathered}
h_{c, w-P g i}=0.884 \times\left(\Delta T^{\prime}\right)^{1 / 3} \\
\Delta T^{\prime}=\left(T_{b w}-T_{g i}\right)+\frac{\left(P_{b w}-P_{g i}\right) \times\left(T_{b w}+273.15\right)}{\left(268,900-P_{b w}\right)}
\end{gathered}
$$

where $P_{w}$ is the vapor pressure on the water temperature and $P_{P g i}$ is the vapor on the temperature of the plexiglass [38]:

$$
\begin{aligned}
& P_{w}=\exp \left(25.317-\frac{5144}{T_{w}+273.15}\right) \\
& P_{P g i}=\exp \left(25.317-\frac{5144}{T_{P g i+273.15}}\right)
\end{aligned}
$$

The evaporation coefficient of the heat transfer from the basin water to the internal surface of the plexiglass cover is:

$$
h_{e, w-P g i}=16.273 \times 10^{-3} h_{c, w-P g i} \times \frac{\left(P_{w}-P_{P g i}\right)}{\left(T_{w}-T_{P g i}\right)}
$$

The coefficient of the heat transfer by radiation from the basin water to the inner surface of the plexiglass cover is as follows [39]:

$$
h_{r, w-P g}=\varepsilon_{e f f} \sigma\left[\left(T_{w}+273.15\right)^{2}-\left(T_{g i}+273.15\right)^{2}\right] \times\left[T_{w}+T_{P g}+546\right]
$$

where $\varepsilon_{e f f}$ is the effective emissivity of the water surface to the plexiglass cover:

$$
\varepsilon_{e f f}=\frac{1}{\left(\frac{1}{\varepsilon_{w}}+\frac{1}{\varepsilon_{P g}}-1\right)}
$$

where $\varepsilon_{b w}$ is the emittance of the basin water. 


\subsubsection{Plexiglass Cover (Pg)}

The equation of the energy balance for the plexiglass cover has been adapted as follows:

The Inner Surface of the Plexiglass Cover (Pgi)

The absorption rate of solar energy by the plexiglass cover; the rate of heat transferred by convection, radiation, and evaporation from the basin water to the inner surface of the plexiglass cover; the rate of heat transfer by convection, radiation, and evaporation from the outer surface of the hollow cylinder to the inner surface of the plexiglass cover; and the rate of heat transfer by convection and evaporation from the inner surface of the hollow cylinder to the inner surface of the plexiglass cover are equivalent to the rate of energy storage in a plexiglass cover and the rate of heat transferred by conduction through the plexiglass cover (from the inner to the outer surface of the plexiglass cover) and are as follows:

$$
\begin{gathered}
I(t) \times \alpha_{P g} \times A_{P g}+Q_{t, w-P g i}+Q_{t, h c o-P g i}+Q_{t, h c i-P g i}=m_{p g} \times C p_{P g} \times \frac{d T_{p g}}{d t}+Q_{c o n d-P g} \\
I(t) \times \alpha_{P g} \times A_{P g}+\left[h_{C, w-P g i}+h_{r, w-P g i}+h_{e, w-P g i}\right] \times\left(A_{b}-A_{s u}\right) \times\left(T_{w}-T_{P g i}\right) \\
+\left[h_{C, w-P g i}+h_{r, w-P g i}+h_{e, w-P g i}\right] \times A_{e a, h c} \times\left(T_{h c o}-T_{P g i}\right)+\left[h_{C, h c i-P g i}+h_{e, h c i-P g i}\right] \times A_{e a, h c} \times\left(T_{h c i}-T_{P g i}\right) \\
=m_{p g} \times C p_{P g} \times \frac{d T_{g}}{d t}+\frac{K_{g}}{t h_{P g}}\left(T_{P g i}-T_{P g o}\right)
\end{gathered}
$$

where $A_{P g}$ is the plexiglass cover area $\left(\mathrm{m}^{2}\right), C p_{P g}$ denotes the heat capacity of the plexiglass cover $\left(\mathrm{J} / \mathrm{kg} .{ }^{\circ} \mathrm{C}\right), d T_{P g}$ represents the difference in temperature between the inner and outer surface of the plexiglass cover $\left({ }^{\circ} \mathrm{C}\right), Q_{\text {cond }-P g}$ is the rate of heat transferred by conduction across the plexiglass cover $(\mathrm{W}), A_{e a, h c}$ is the area of the hollow cylinder $\left(\mathrm{m}^{2}\right), K_{g}$ is the plexiglass cover's thermal conductivity $(\mathrm{W} / \mathrm{m} . \mathrm{k}), t h_{P g}$ is the plexiglass cover's thickness $(0.003 \mathrm{~m})$, and $T_{P g o}$ is the temperature of the outer surface of the plexiglass $\left({ }^{\circ} \mathrm{C}\right)$.

The hollow cylinder's surface area $A_{e a, h c}$ interacts with each element of the plexiglass cover:

$$
A_{e a, h c}=L_{h c} \sum_{i=1}^{n} d x
$$

In the current study, the time step was $0.5 \mathrm{~s}$; this is because it affords us a reasonable calculation period. Using a smaller time step barely affected the results but significantly increased the calculation time. The properties of the moist air, such as thermal diffusivity, thermal conductivity, density, the capacity of specific heat, viscosity, and the pressure of saturated vapor, are taken as follows [40].

In building a prototype simulation of the modified solar water distiller, we considered the basin water and the plexiglass cover as a single unit with an even temperature distribution. Thus, the hollow cylinder was divided into the longitudinal elements of the governing balance equation, which depends on the location of these elements during the turning of the hollow cylinder. Four sectors are shown in Figure 5 along the circumference of the hollow cylinder to receive a variable quantity of rays from the sun base on their exact position at a specific time, as shown in Figure 4. For a specific period $\mathrm{dt}(\mathrm{s})$, the incremental distance $\mathrm{dx}(\mathrm{m})$ was calculated as follows [41]:

$$
d x=\frac{2 \times \pi \times r \times d t}{60 \times N_{h c}}
$$

where $r$ is the hollow cylinder radius (m) and $N_{h c}$ is the number of revolutions per minute for a hollow cylinder (rpm). 
The Outer Surface of the Plexiglass Cover (Pgo)

The rate of heat transfer by conduction $Q_{\text {cond-g }}$ from the inner to the outer surface of the plexiglass cover is equal to the rate of heat transferred from the outer surface of the plexiglass cover by convection $Q_{c, g o-a}$ and radiation $Q_{r, P g o-a}$ to the ambient air. It is calculated as follows:

$$
\frac{K_{P g}}{t h_{P g}}\left(T_{P g i}-T_{P g o}\right)=\left[h_{c, P g o-a}+h_{r, P g o-s k y}\right] \times A_{P g}\left(T_{P g o}-T_{a}\right)
$$

where $h_{c, P g o-a}$ is the convection heat transfer coefficient between the outer plexiglass surface and the ambient air $\left(\mathrm{W} / \mathrm{m}^{2} . \mathrm{k}\right)$ [42]:

$$
\begin{gathered}
h_{c, \text { Pgo-a }}=5.7+2.8 V_{a} \text { for } V_{a}>5 \mathrm{~m} / \mathrm{s} \\
h_{c, \text { Pgo-a }}=2.8+3 V_{a} \text { for } V_{a} \leq 5 \mathrm{~m} / \mathrm{s}
\end{gathered}
$$

$h_{r, P g o-s}$ is the radiation heat transfer coefficient from the outer plexiglass surface to the ambient air at $T_{\text {sky }}$ :

$$
h_{r, g o-s k y}=\varepsilon_{g o} \times \sigma\left[\left(T_{s k y}+273.15\right)^{2}-\left(T_{g o}+273.15\right)^{2}\right] \times\left[T_{s k y}+T_{g o}+546\right]
$$

where $\varepsilon_{g_{0}}$ is the emissivity of the plexiglass on its outer surface.

\subsubsection{Water Film Thickness $\left(t h_{w f}\right)$}

The water film thickness around the internal and external surface of the rotating hollow cylinder at the point the cylinder exits the water can be considered a flat surface with the same angle of contact. Therefore, the dimensionless uniform thickness $t h_{f w 0}$ can be calculated as a function of the number of fluid properties, the contact angle $\theta_{c}$, and a dimensionless capillary number.

To extend this theory from a flat plate to a rotating hollow cylinder, the position of the measurement $\theta_{j}$ and the thickness of the water film $t h_{f w t}(\mathrm{~m})$ were calculated at the top of the rotating hollow cylinder, which was first estimated as a function of $t h_{f w 0}$. The water film's thickness $t h_{f w}(\mathrm{~m})$ at a certain position is calculated as follows [43]:

$$
t h_{f w t}=t h_{f w}-\frac{\rho_{w} \times g \times t h_{f w}{ }^{3} \times \sin \theta_{j}}{3 \times \mu_{w} \times V_{h c}}=t h_{f w 0}-\frac{\rho_{w} \times g \times t h_{f w 0}{ }^{3} \times \sin \theta_{j}}{3 \times \mu_{w} \times V_{h c}}
$$

where $\rho_{w}$ is the water density $\left(\mathrm{kg} / \mathrm{m}^{3}\right), \mu_{w}$ is the water dynamic viscosity $(\mathrm{kg} / \mathrm{m} . \mathrm{s})$, and $V_{h c}$ is the peripheral speed of the hollow cylinder. This is calculated in $(\mathrm{m} / \mathrm{s})$ [41]:

$$
V_{h c}=\frac{2 \times \pi \times r \times N_{h c}}{60}
$$

\subsubsection{The Hourly Yield of Distillate Water from the Modified Solar Distiller}

The hourly produced distillate of water, $m_{\text {hdwm }}$, for the modified solar distiller in $\left(\mathrm{kg} / \mathrm{m}^{2} . \mathrm{hr}\right)$ was calculated by multiplying the evaporation heat transfer coefficient between the basin water and the inside surface of the plexiglass cover $h_{e, b w-g i}$, the outside surface of the hollow cylinder and the inside surface of the plexiglass cover $h_{e, h c o-g i}$, and the inside surface of the hollow cylinder and the surface of the plexiglass cover $h_{e, h c i-g i}$ by the temperature, the temperature of the inside surface of the plexiglass temperature $T_{P g i}\left({ }^{\circ} \mathrm{C}\right)$, and 3600 .The outcomes were divided by the average latent heat $h_{f g}$ at the average temperature of the basin water [44]: 
$m_{h d w w}=\left[\frac{h_{e, b w-g i} \times 0.8 A_{b} \times\left(T_{b w}-T_{P g i}\right)+h_{e, h c o-P g i} \times A_{e a, h c} \times\left(T_{h c o}-T_{P g i}\right)+h_{e, h c i-P g i} \times A_{e a, h c} \times\left(T_{h c o}-T_{P g i}\right) \times\left(T_{h c i}-T_{P g i}\right)}{h_{f g}}\right] \times 3600$

where

$$
h_{f g}=10^{3}\left[2501.9-2.40706 \times T_{w}+1.192217 \times 10^{-3} \times T_{w}^{2}-1.5863 \times 10^{-5} \times T_{w}^{3}\right]
$$

\subsubsection{The Hourly Efficiency of the Modified Solar Distiller}

The hourly efficiency, $\eta_{h m}$, of the modified solar still has been estimated by multiplying the cumulative distillate freshwater $m_{h d w m}$ and by the average latent heat $h_{f g}$. Then, the results were divided by the total solar radiation consumed $I(t)\left(\mathrm{W} / \mathrm{m}^{2}\right)$, the period $\Delta t$ (3600 s) of the enhanced solar still, and the power consumption of the water pump $(8 \mathrm{~W})$ and the DC motor $(1.2 \mathrm{~W})$.

$$
\eta_{h m}=\frac{m_{\text {hdwm }} \times h_{f g}}{I(t) \times A_{b} \times 3600+I(t)_{S C} \times A_{S C} \times 3600+\left(P_{\text {motor }}+P_{\text {pump }}\right) \times 3600} 100 \%
$$

where $I(t)_{S C}$ is the solar radiation absorbed by the flat plate solar collector $\left(\mathrm{W} / \mathrm{m}^{2}\right)$ and $A_{S C}$ is the surface area of the solar collector $\left(\mathrm{m}^{2}\right)$. Table 2 shows the theoretical parameters used in the mathematical model.

Table 2. Theoretical parameters.

\begin{tabular}{cccc}
\hline Parameter & Value & Parameter & Value \\
\hline$A_{\boldsymbol{b}}$ & $0.5 \mathrm{~m}^{2}$ & $\varepsilon_{b}=\varepsilon_{h c}$ & $0.31[45]$ \\
\hline$A_{g}$ & $0.825 \mathrm{~m}^{2}$ & $\varepsilon_{w}$ & $0.963[46]$ \\
\hline$m_{w}$ & $25 \mathrm{~kg}$ & $\varepsilon_{g}$ & $0.88[45]$ \\
\hline $\boldsymbol{m}_{g}$ & $3.14 \mathrm{Kg}$ & $C P_{b}=C P_{h c}$ & $460[46]$ \\
\hline$\alpha_{\boldsymbol{b}}=\alpha_{h c}$ & $0.95[46]$ & $C P_{w}$ & $4180[45]$ \\
\hline$\alpha_{w}$ & $0.05[46]$ & $C P_{g}$ & $1270[45]$ \\
\hline$\alpha_{g}$ & $0.05[45]$ & $K_{g}$ & $0.19-0.20[45]$ \\
\hline$\tau_{w}$ & $0.95[47]$ & $K_{i}$ & $0.12[45]$ \\
\hline$\tau_{g}$ & $0.92[45]$ & $L_{i}$ & $0.018[45]$ \\
\hline
\end{tabular}

\subsection{Initial and Boundary Conditions}

The analysis of the numerical model of the conventional and modified solar water stills requires the initial boundary conditions of different parameters. These include the temperatures of the basin liner $\left(T_{b}\right)$, the basin water $\left(T_{w}\right)$, the hollow cylinder $\left(T_{h c}\right)$, and the inner $T_{g i}$ and outer $T_{g o}$ plexiglass cover surfaces. Initial weather parameters (such as ambient air temperature $\left(T_{a}^{0}\right)$ and wind speed $\left.\left(V_{a}^{0}\right)\right)$, the design and operational parameters, and the temperature of the various parameters were expressed at the start of the program at a time equal to zero: $T_{g o}^{0}, T_{g i}^{0}, T_{b}^{0}, T_{w}^{0}$, and $T_{h c}^{0}$. Then, the energy balance equations were used to determine the various parameters of the temperature values in the next period:

1. From $T_{b}^{0}, T_{w}^{0}, T_{h c^{\prime}}^{0}, T_{g i}^{0}$ and $T_{g o}^{0}$ and Equation (5), $T_{b}^{1}$ has been estimated in the next period.

2. From $T_{b}^{1}, T_{w}^{0}, T_{h c}^{0}, T_{g i}^{0}$ and $T_{g o}^{0}$ and Equation (30), $T_{w}^{1}$ has been estimated in the next period.

3. From $T_{b}^{1}, T_{w}^{1}, T_{h c}^{0}, T_{g i}^{0}$ and $T_{g o}^{0}$ and Equation (13), $T_{h c}^{1}$ has been estimated in the next period.

4. From $T_{b}^{1}, T_{w}^{1}, T_{h c^{\prime}}^{1} T_{g i}^{0}$ and $T_{g o}^{0}$ and Equation (39), $T_{g i}^{1}$ has been estimated in the next period.

5. From $T_{b}^{1}, T_{w}^{1}, T_{h c^{\prime}}^{1} T_{g i}^{1}$ and $T_{g o}^{0}$, and Equation (42), $T_{g o}^{1}$ has been estimated in the next period.

6. The energy balance equation of the hollow cylinder has been derived for each surface element of the hollow cylinder depending on its position, as shown in Figure 1. 
It is also assumed in the boundary conditions of the theoretical models that the temperatures of the basin water and the first hollow cylinder element to leave the basin water are equal.

7. It is assumed that the water film element's temperature, which is adjacent to the hollow cylinder's surface, is equal to its temperature $\left(T_{w f}=T_{h c}\right)$.

8. In the current theoretical analysis, the programming language Fortran 90 has been used to evaluate the distillate water production from the solar still and its efficiency. The time step $0.5 \mathrm{~s}$ was used as this period gave a reasonable amount of computational time: the use of smaller time steps barely affected the results but significantly increased calculation time, as is shown in Figure 4.

\section{Results and Discussion}

\subsection{Experimental Results}

Solar radiation, wind speed, and ambient temperature can be considered as the most important environmental factors influencing solar still performance. Figure 6A represents the variation in total solar radiation intensity during the test periods in the climate conditions of Yekaterinburg, Russia. The highest solar radiation intensity was in July and the lowest in October. The peaks for all months were between 12:00 p.m. and 1:00 p.m. Figure $6 \mathrm{~B}$ shows the variation of the hourly ambient temperature during the four typical days. The thermal variation of the ambient temperature was the same as the solar radiation. This is because, after sunrise, the sun rays transfer heat energy to regions on the Earth's surface and the ambient air [24]. All the curves had the same variation trend. The maximum temperature was between 4:00 p.m. and 5:00 p.m., while the minimum temperature was at 8 am. The highest levels for the ambient temperature were recorded in July at about $34.3^{\circ} \mathrm{C}$, while the lowest levels were recorded in September at about $22.4{ }^{\circ} \mathrm{C}$. Figure $6 \mathrm{C}$ shows the variation of hourly wind velocity during the four typical days. It seems clear that the trend fluctuates in different months. It was generally strong at midday.

Figure 7 illustrates the hourly variation of the intensity of solar radiation, the ambient air temperature, and the temperatures at different points for the basin plate, the basin water, and the plexiglass cover for the conventional and modified solar water distillers for the four typical days: (1) 19 June, (2) 17 July, (3) 22 August, and (4) 15 September 2019. As demonstrated in this figure, the temperatures were affected by environmental factors, such as ambient temperature and solar radiation. The basin plate, basin water, and plexiglass cover temperatures in the modified solar distiller were higher than their counterparts in the conventional solar water distiller. The process of preheating the water in the flat plate solar water collector and the rotation of the hollow cylinder with a black coating, therefore, increased the heat content inside the system. It was also observed that the highest temperatures were recorded in July and the lowest levels in September 2019 due to different weather conditions. In July, the temperatures of the basin plate, basin water, and plexiglass cover of the conventional solar distiller were about $58.3^{\circ} \mathrm{C}, 56.1^{\circ} \mathrm{C}$, and $46.1^{\circ} \mathrm{C}$, while the temperatures of the modified solar distiller when integrated were about $65.16^{\circ} \mathrm{C}, 64.4^{\circ} \mathrm{C}$, and $50.4{ }^{\circ} \mathrm{C}$, respectively. As for September, the temperatures of the basin plate, basin water, and plexiglass cover of the conventional solar distiller were $45.36{ }^{\circ} \mathrm{C}, 43.8^{\circ} \mathrm{C}$, and $35.6^{\circ} \mathrm{C}$, while the temperatures of the modified solar distiller were about $50.08{ }^{\circ} \mathrm{C}, 48.6^{\circ} \mathrm{C}$, and $37.3^{\circ} \mathrm{C}$, respectively. 

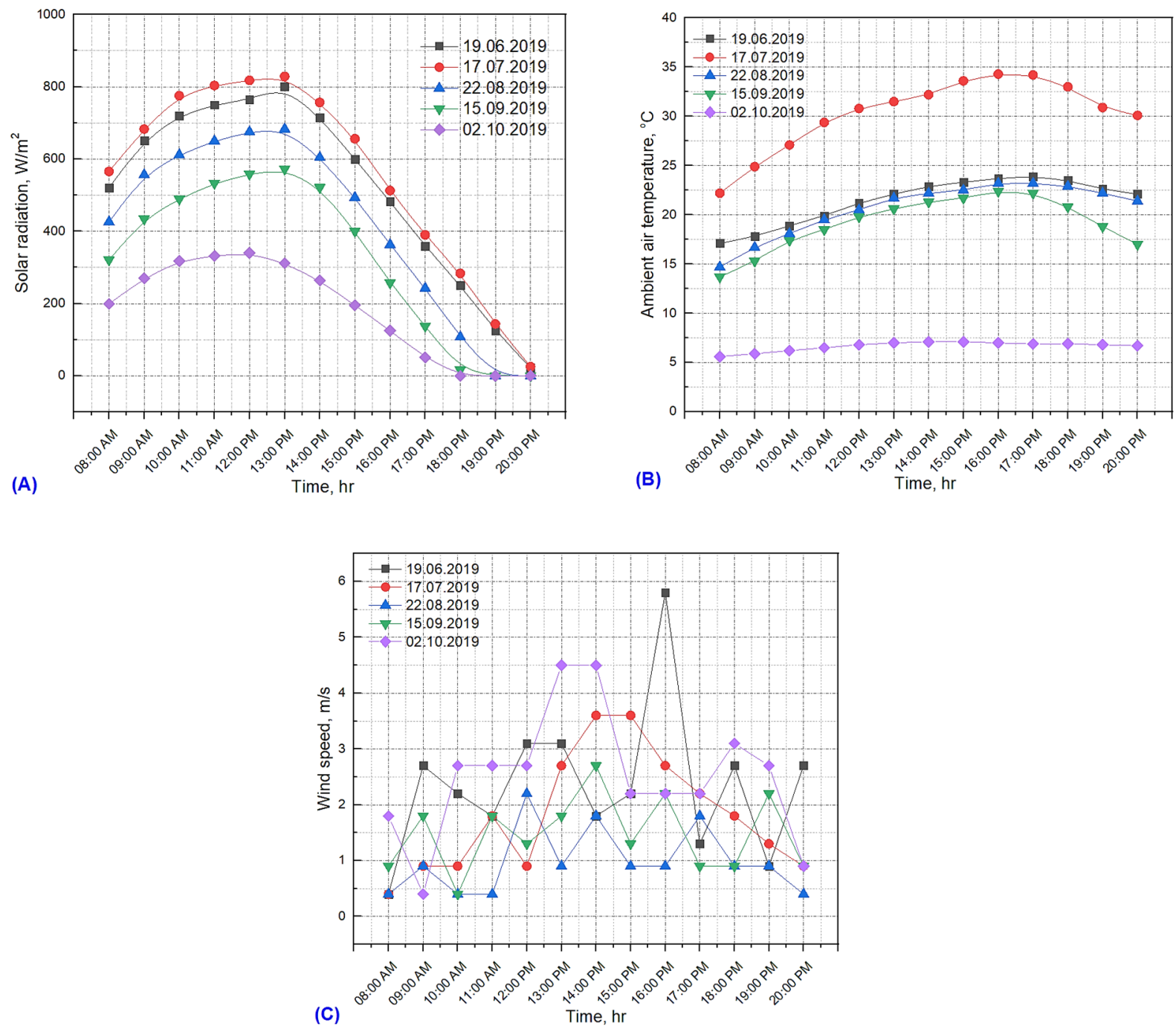

Figure 6. Variation of hourly weather parameters: (A) solar radiation intensity, (B) ambient temperature, and (C) wind speed over four months during 2019.
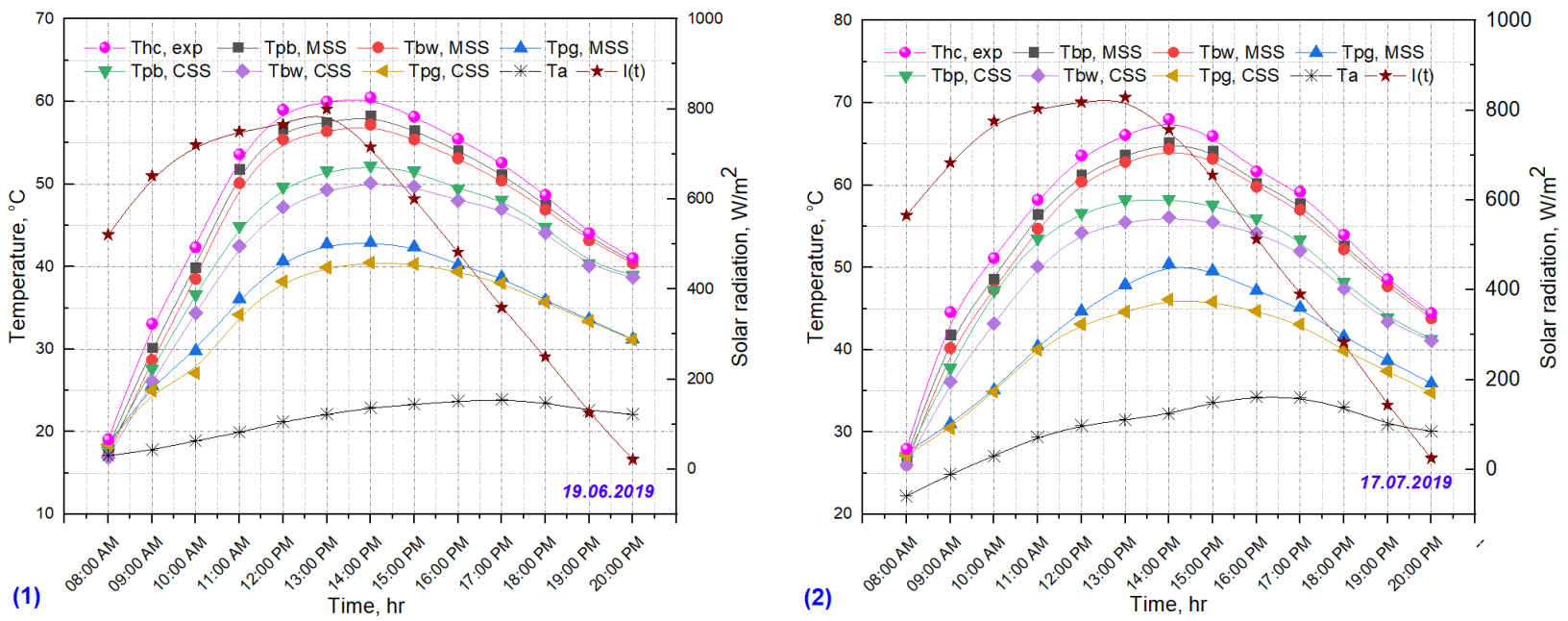

Figure 7. Cont. 

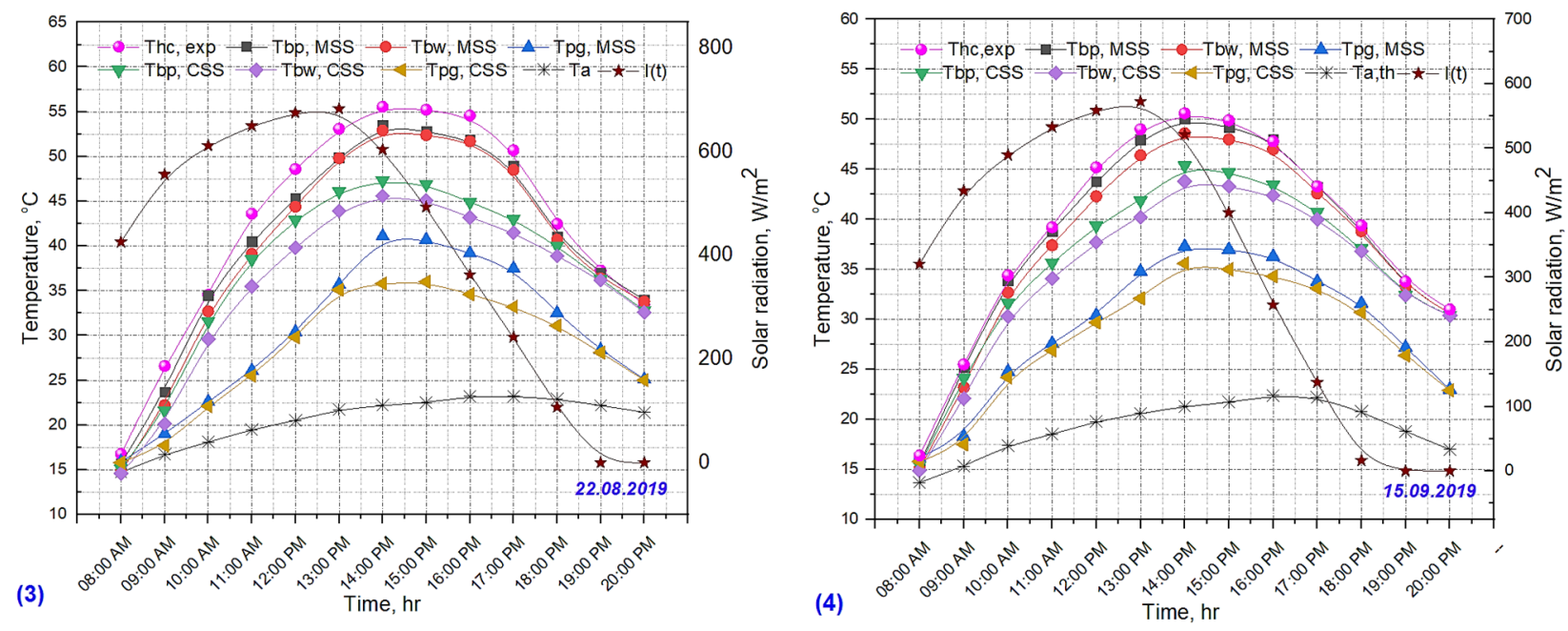

Figure 7. Hourly change in solar radiation intensity, ambient air temperature, and temperatures at different points for the basin plate, the basin water, and the plexiglass cover of CSS and MSS on four typical days: (1) 19 June, (2) 17 July, (3) 22 August, and (4) 15 September 2019 in the climate conditions of Yekaterinburg, Russia.

Figure 8 represents the hourly variation of the solar radiation and the amount of cumulative distillate water from the CSS and the MSS for the typical days $(1,2,3$, and 4). From this figure, increased cumulative distillate water from the modification and conventional solar stills was observed as the solar radiation intensity and ambient air temperature increased until they reached a maximum point at 4 p.m. Although the solar radiation intensity decreased after about 6 p.m., the productivity of the solar MSS and CSS continued because the basin water had sufficient potential thermal energy to discharge at sundown [34], in addition to the decrease in the temperature of the plexiglass cover due to the lower temperature of the surrounding air. It was also observed that the freshwater productivity of the modified solar distiller was higher than that of the conventional solar still on 16 June, 17 July, 22 August, and 15 September 2019. This was due to the continuous formation of a thin layer of saltwater on the inner and outer surfaces of the rotating cylinder, which had sufficient time to evaporate at a rotational speed of $0.5 \mathrm{rpm}$ and thus increase the rate of evaporation. When the hollow cylinder rotates, disturbances occur in the basin water and the water vapor adjacent to the surfaces of the cylinder and above the surface of the basin water. This turbulence leads to the circulation of this vapor to the inner plexiglass surface, thus increasing the rate of condensation on the plexiglass cover.

The cumulative freshwater production was recorded as $2600 \mathrm{~mL} / \mathrm{m}^{2}, 2800 \mathrm{~mL} / \mathrm{m}^{2}$, $2200 \mathrm{~mL} / \mathrm{m}^{2}$, and $1600 \mathrm{~mL} / \mathrm{m}^{2}$ for the conventional solar still on 19 June, $17 \mathrm{July}, 22$ August, and 15 September 2019, respectively, compared to $9900 \mathrm{~mL} / \mathrm{m}^{2}, 11,100 \mathrm{~mL} / \mathrm{m}^{2}$, $8600 \mathrm{~mL} / \mathrm{m}^{2}$, and $6400 \mathrm{~mL} / \mathrm{m}^{2}$ for the modified solar still, respectively, with increases of $281 \%, 296 \%, 290 \%$, and $300 \%$. Due to this, the thin layer of saltwater over the hollow cylinder's surface has a low heat capacity. Moreover, the rotating hollow cylinder increased the surface area for receiving more solar energy compared to the conventional solar still, which increased the rates of evaporation for the basin water [48]. The rate of heat transfer between the cylinder surface and the film water layer was higher than between the basin liner and the saltwater of the CSS, thus increasing the rate of evaporation and distillation. 

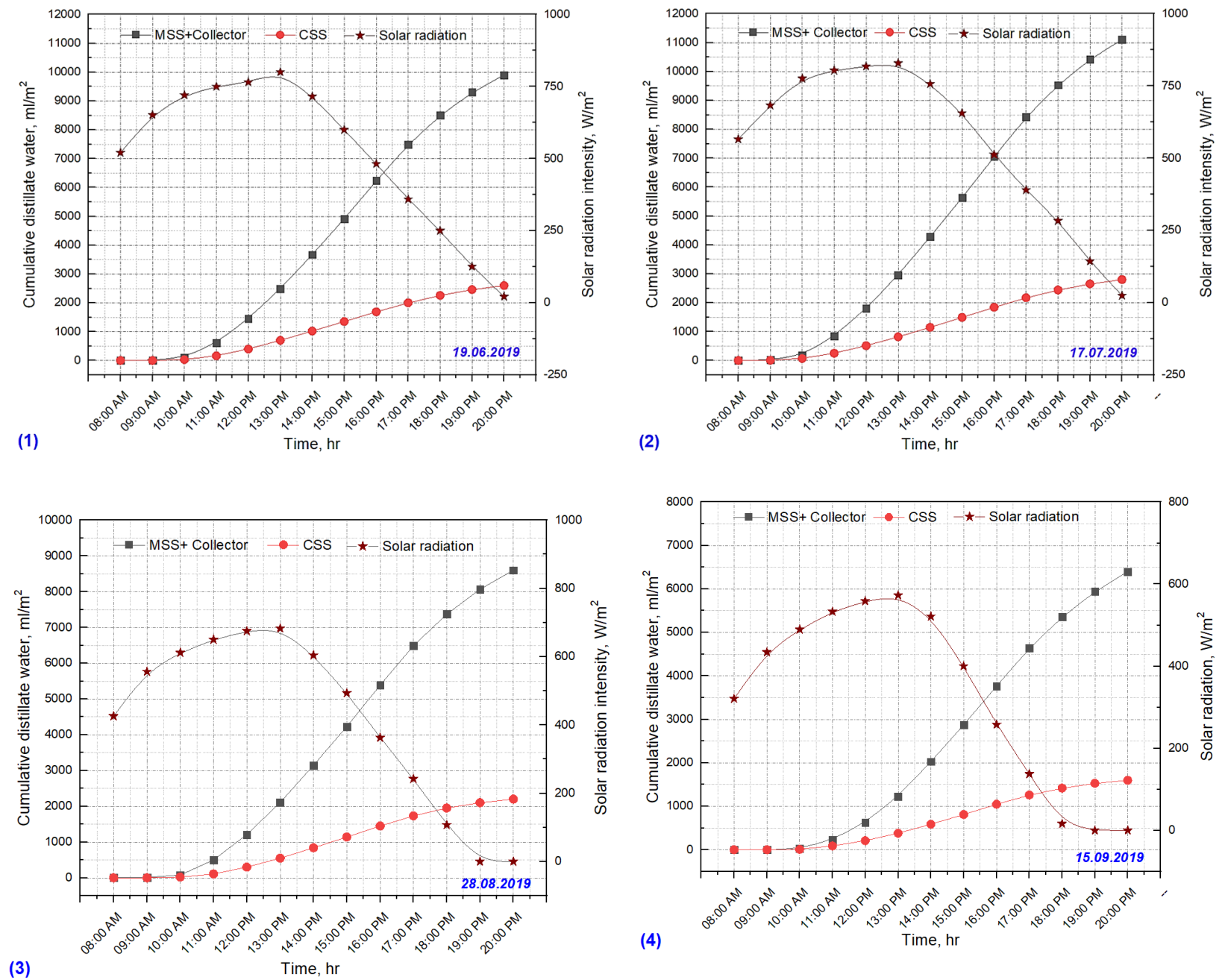

Figure 8. Hourly change in the intensity of solar radiation and the cumulative distillate water for the modified solar distiller and the conventional solar distiller for the typical days: (1) 19 June, (2) 17 July, (3) 22 August, and (4) 15 September 2019 in the climate conditions of Yekaterinburg, Russia.

\subsection{Model Validation}

The theoretical model was validated by comparing its results with the corresponding experimental results. The experimentally defined design and the operational and metrological parameters were used for the theoretical simulation. Figures 9-11 illustrate the comparison of the theoretical and experimental distillate water yields and the thermal efficiency for the MSS and the CSS at $0.5 \mathrm{rpm}$. The results of the theoretical model show good agreement with the data from the experimental work. The relative difference between the experimental results and the theoretical model is 3.9\% for the temperatures and $8.39 \%$ for the productivity. That is, the same trend shows an average total deviation of $6.14 \%$, which is accredited to the measurements of the experimental data. These deviations between the experimental and numerical results may be because the weather conditions in the theoretical model were considered as constant per hour. In the experimental tests, it may have taken two or three hours (that is, around 10 a.m. or 11 a.m.) in the early daylight hours to raise the basin water's temperature, especially for the conventional solar distiller. In the mathematical model, the case is ideal, depending on the weather conditions; so, it could take $1 \mathrm{~h}$ (that is, around 9 a.m.) to raise the basin water's temperature. 

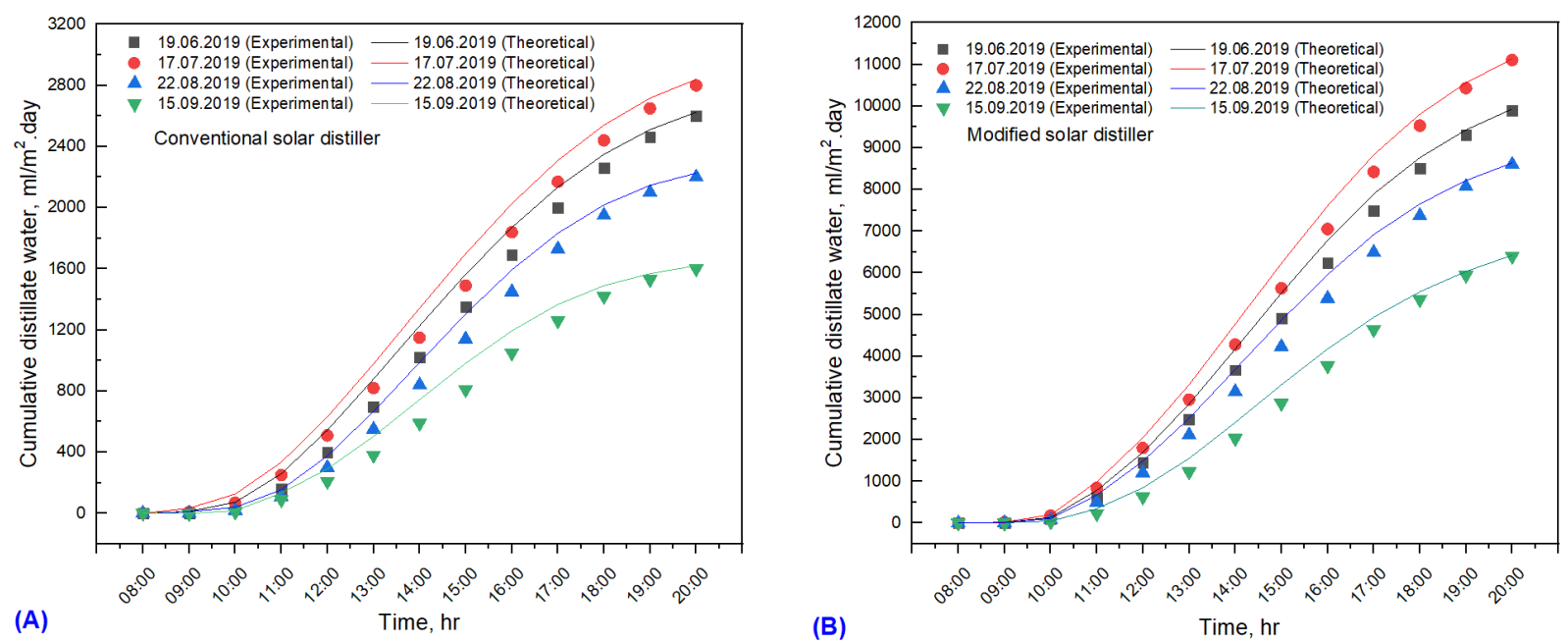

Figure 9. Hourly change in the cumulative distillate water for (A) the conventional solar distiller and (B) the modified solar distiller for the theoretical model and experimental results on 19 June 2019, 17 July 2019, 22 August 2019, and 15 September 2019.
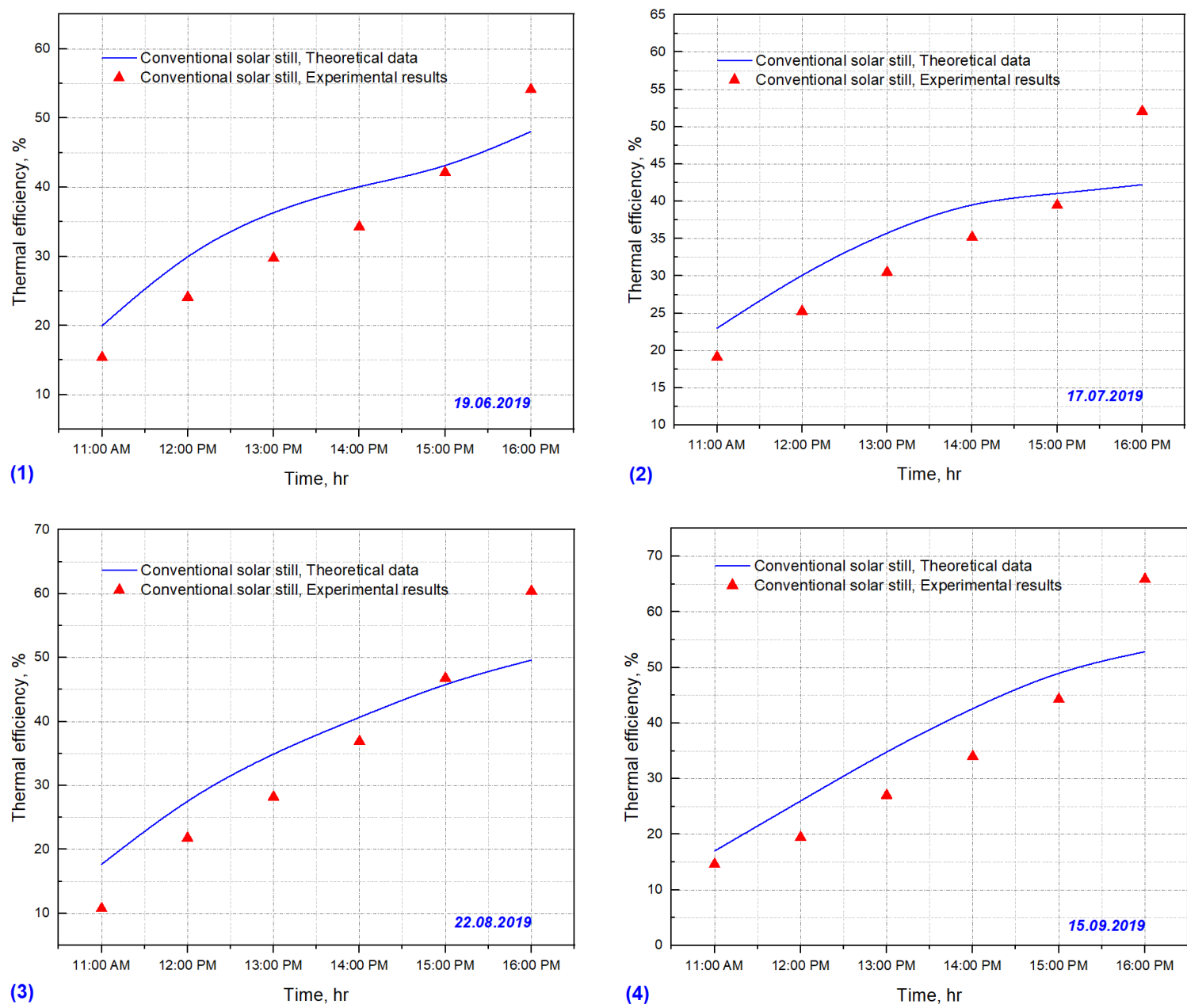

(2)

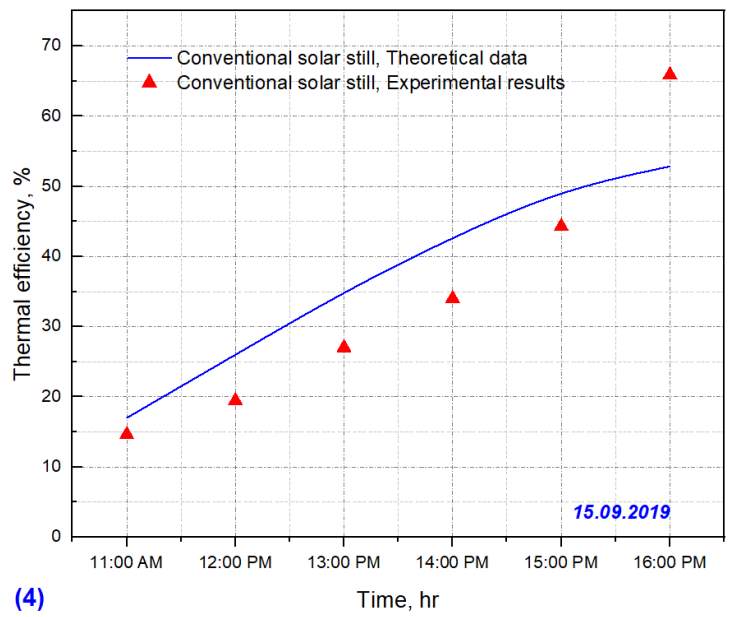

Figure 10. Hourly change in the thermal efficiency of the conventional solar distiller for the theoretical model and experimental results for (1) 19 June, (2) 17 July, (3) 22 August, and (4) 15 September 2019. 

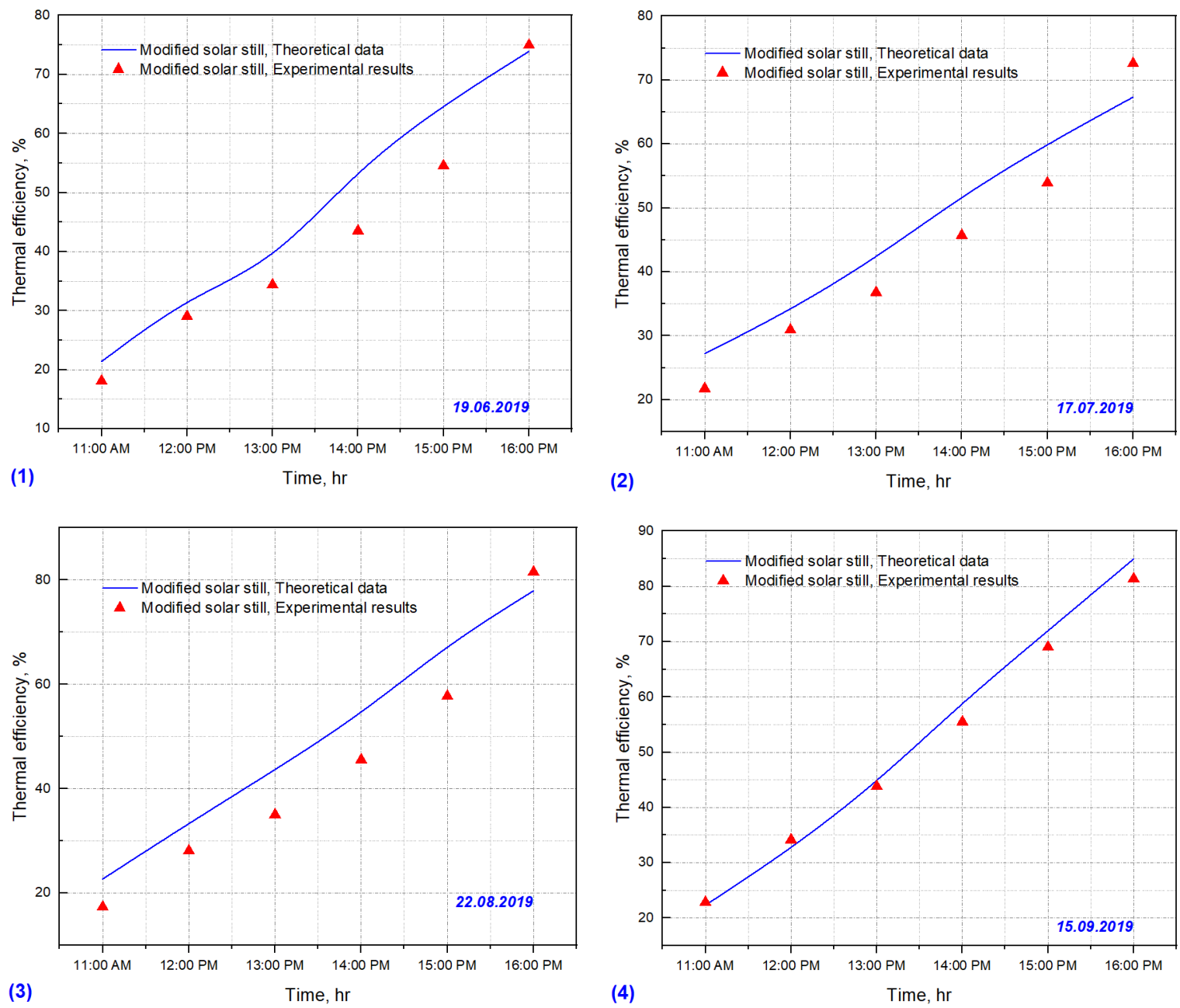

Figure 11. Hourly change in the thermal efficiency of the modified solar distiller for the theoretical model and experimental results for (1) 19 June, (2) 17 July, (3) 22 August, and (4) 15 September 2019 in the climate conditions of Yekaterinburg, Russia.

Figures 10 and 11 illustrate the theoretical and experimental variation of hourly efficiency for the modified and conventional solar stills for (1) 19 June, (2) 17 July, (3) 22 August, and (4) 15 September 2019. From these figures, it is noted that the experimental hourly efficiency values are slightly less than the theoretical model for all test days and both types of solar stills (MSS and CSS). This demonstrates a good agreement between the numerical and experimental results. From Figures 10 and 11, it was discovered that the efficiencies of the modified and conventional solar stills were affected by the intensity of the solar radiation and the quantity of distillate water production. Therefore, the hourly efficiency rises with time until it reaches a peak value at 4 p.m. due to the continuation of the distillation process (continued evaporation with decreased intensity of solar radiation and lower ambient temperature). Thus, the loss of heat from the glass cover to the ambient air at this time augmented the process of condensation on the glass cover's inner surface. It was observed that the average optimal hourly efficiency of the CSS for 19 June, 17 July, 22 August, and 15 September 2019 was about $54 \%, 52 \%, 60.38 \%$, and $65.8 \%$, respectively, which was less than the hourly efficiency of the MSS: $74.9 \%, 72.58 \%, 80.5 \%$, and $81.37 \%$, respectively. Normally, the hourly efficiency of the conventional solar still was less than the hourly efficiency of the modified solar still. The effective evaporative area of the modified solar still was larger than in the CSS, and there was a large difference in temperature between the glass and the basin water in the modified solar still. 


\subsection{Analysis of Production Cost}

The total fixed cost $(F C)$ of the modified and conventional solar stills are presented in Table 3: approximately USD 315 and USD 82, respectively. To calculate the average value of the cost of one cumulative liter of distillate water output, the variable cost $(V C)$ and the total cost (TC) should be computed using [48]:

$$
T C=F C+V C
$$

Table 3. Capital cost for the construction and installation of the solar stills.

\begin{tabular}{cccc}
\hline Materials & Quality & CSS (USD) & MSS (USD) \\
\hline MDF Wooden Board $1.8 \mathrm{~cm}$ thickness & $2 \mathrm{~m}^{2}$ & 14 & 14 \\
\hline Plexiglas's cover $0.3 \mathrm{~cm}$ thickness & $1.2 \mathrm{~m}^{2}$ & 15 & 15 \\
\hline Galvanized stainless plate, $0.1 \mathrm{~cm}$ & $1.2 \mathrm{~m}^{2}$ & 11 & 11 \\
\hline Galvanized stainless plate, $0.1 \mathrm{~cm}$ & $1 \mathrm{~m}^{2}$ & - & 125 \\
\hline Photovoltaic panel $(110 \mathrm{~W})+$ accessories & 1 piece & - & 25 \\
\hline Battery & 1 piece & - & 14 \\
\hline DC- motor 12 V + regulator & 1 piece & - & 10 \\
\hline Flat plate solar water collector & 1 piece & - & 1 \\
\hline DC Water Pump & 1 piece & 1 & 3 \\
\hline A mechanical floater & 1 piece & 3 & 3 \\
\hline Spray paint heat-resistant & 2 pieces & 3 & 15 \\
\hline Heat-resistant silicone glue & 2 pieces & 15 & 20 \\
\hline Feedwater system & - & 20 & 315 \\
\hline Extra work accessories & - & 82 &
\end{tabular}

Assume the variable cost $(V C)$ equals $0.0916 \mathrm{FC}$ per year and the expected solar still lifetime is 10 years; therefore, the total cost for the CSS would be TC $=82+0.0916 \times 82$ $\times 10=$ USD 157.112 and for the MSS it would be TC $=315+0.0916 \times 315 \times 10=$ USD 603.54. The lowest average cumulative distillate water yield daily is obtainable from the experimental test data. It was found to be $2.8 \mathrm{~L} /$ day for the CSS and $11.1 \mathrm{~L} /$ day for the MSS. The production cost of one liter if the two solar stills operate for 180 days per annum (which represents the average number of sunny days per year in Yekaterinburg) was calculated. The total cumulative distillate water output during the solar still's lifetime is $2.8 \times 180 \times$ $10=5040 \mathrm{~L}$ from the CSS and $11.1 \times 180 \times 10=19,980 \mathrm{~L}$ from the MSS. The cost of one liter from the conventional solar still $=157.112 / 5040=0.0312 \mathrm{USD} / \mathrm{lit}$, and for the modified solar still $=603.54 / 19,980=0.0302$ USD $/$ lit.

\section{Conclusions}

According to what has been discussed during the analysis of the results, it is possible to conclude the following:

1. There was a significant improvement in the production of freshwater as a result of the integration of the modified solar still (MSS) with a hollow cylinder and an outdoor solar collector compared to the CSS due to the increase in the evaporation surface area and the reduction in the dimensions between the evaporation surface and the plexiglass cover. The productivity of the MSS improved by $281-300 \%$ relative to the CSS, depending on environmental constraints, such as the intensity of solar radiation, the ambient air temperature, and the relative humidity from June to September 2019. 
2. Numerical analysis (the finite difference method) can be used to study the complex phenomena involved without using costly prototypes and complex experimental works. Using the programming language Fortran 90, theoretical calculations were carried out. In general, the production cost of a liter of fresh water using the MSS was USD 0.0302 and USD 0.0312 for the CSS. It can therefore be said that the proposed improvement in this study led to a reduction in the cost of distillate water.

3. A rotating cylinder's surface area for evaporation and absorption can be increased through the addition of a fin or by corrugating its surface.

4. The rotating cylinder's surface can be kept wet through the use of a wick on its surface.

5. The continuous heating of the cylinder surface can be assured through the installation of a phase-changing material (e.g., paraffin wax) on the internal surface.

Author Contributions: Conceptualization, N.T.A., S.E.S., O.M.A., M.H.M. and E.B.A.; methodology, N.T.A., S.E.S., O.M.A., M.H.M. and E.B.A.; software, N.T.A., S.E.S., O.M.A., M.H.M. and E.B.A.; validation N.T.A., S.E.S., O.M.A., M.H.M. and E.B.A.; formal analysis, N.T.A., S.E.S., O.M.A., M.H.M. and E.B.A.; investigation, N.T.A., S.E.S., O.M.A., M.H.M. and E.B.A.; resources, N.T.A., S.E.S., O.M.A., M.H.M. and E.B.A.; data curation, N.T.A., S.E.S., O.M.A., M.H.M. and E.B.A.; writing-original draft preparation, N.T.A., S.E.S., O.M.A., M.H.M. and E.B.A.; writing-review and editing, N.T.A., O.M.A., M.H.M. and E.B.A.; visualization, N.T.A., S.E.S., O.M.A., M.H.M. and E.B.A.; funding acquisition, E.B.A. All authors have read and agreed to the published version of the manuscript.

Funding: This research received no external funding.

Institutional Review Board Statement: Not applicable.

Informed Consent Statement: Not applicable.

Data Availability Statement: All data are available in the text.

Conflicts of Interest: The authors declare no conflict of interest.

\section{Nomenclature}

$\begin{array}{llll}\text { Symbol } & \text { Description } & \text { Symbol } & \text { Description } \\ \text { MSS } & \text { Modified solar still } & \mathrm{h} & \text { The coefficient of heat transfer } \\ \text { CSS } & \text { Conventional solar still } & \mathrm{n} & \text { Number of days in the year } \\ \text { MDF } & \text { Medium Density Fiberboard } & \mathrm{N} & \text { Number of revolutions } \\ \text { PVC } & \text { Polyvinyl Chloride } & \mathrm{P} & \text { Pressure } \\ \text { LCD } & \text { Liquid Crystal Display } & \mathrm{r} & \text { Radius } \\ \mathrm{Q} & \text { Thermal energy transferred } & \mathrm{t} & \text { Time } \\ \mathrm{S} & \text { Standard deviation } & \mathrm{T} & \text { Temperature } \\ S . E & \text { Standard error } & \text { Th, L } & \text { Thickness } \\ I(t) & \text { Solar radiation intensity } & \mathrm{V} & \text { Velocity } \\ A & \text { Surface area } & \eta & \text { Efficiency } \\ b & \text { Basin } & \alpha & \text { Absorptivity of the surface } \\ \mathrm{W} & \text { Basin water } & v & \text { Kinematic viscosity } \\ h_{c} & \text { Hollow cylinder } & \mu & \text { Dynamic viscosity } \\ P g & \text { Plexiglass cover } & \varepsilon & \text { Emittance of the surface } \\ \mathrm{M} & \text { Mass } & \beta & \text { Angle of tilt } \\ \rho & \text { Density } & \sigma & \text { Stefan-Boltzmann constant } \\ C_{P} & \text { Specific heat } & N_{u} & \text { Nusselt number } \\ \mathrm{G} & \text { Gravitational acceleration } & P_{r} & \text { Prandtl number } \\ \mathrm{K} & \text { Thermal conductivity } & R_{a} & \text { Rayleigh number } \\ h_{f g} & \text { Latent heat } & R_{e} & \text { Reynolds number } \\ \text { FC } & \text { Total fixed cost } & \text { PV } & \text { Photovoltaic } \\ \text { VC } & \text { Variable cost } & \text { DC } & \text { Direct current } \\ \text { TC } & \text { Total cost } & \text { MDF } & \text { Medium-density fiber } \\ & & & \end{array}$




\section{References}

1. Swatuk, L.; McMorris, M.; Leung, C.; Zu, Y. Seeing "invisible water": Challenging conceptions of water for agriculture, food and human security. Can. J. Dev. Stud. 2015, 36, 24-37. [CrossRef]

2. Senevirathna, S.; Ramzan, S.; Morgan, J. A sustainable and fully automated process to treat stored rainwater to meet drinking water quality guidelines. Process Saf. Environ. Prot. 2019, 130, 190-196. [CrossRef]

3. Chaibi, M.T. An overview of solar desalination for domestic and agriculture water needs in remote arid areas. Desalination 2000, 127, 119-133. [CrossRef]

4. Dev, R.; Tiwari, G.N. Characteristic equation of a passive solar still. Desalination 2009, 245, 246-265. [CrossRef]

5. Sayato, Y. WHO Guidelines for Drinking-Water Quality. Eisei Kagaku 1989, 35, 307-312. [CrossRef]

6. Gorchev, H.G.; Ozolins, G. Guidelines for Drinking-Water Quality, 3rd ed.; WHO: Geneva, Switzerland, 2004 ; Volume 1, p. 564. [CrossRef]

7. UN. Policies, Action, Change, Waters; ABOUT UN-WATER: New York, NY, USA, 2020; pp. 9-10.

8. Tiwari, G.N.; Singh, H.N.; Tripathi, R. Present status of solar distillation. Solar Energy 2003, 75, 367-373. [CrossRef]

9. Khawaji, A.D.; Kutubkhanah, I.K.; Wie, J.M. Advances in seawater desalination technologies. Desalination 2008, 221, 47-69. [CrossRef]

10. García-Rodríguez, L. Seawater desalination driven by renewable energies: A review. Desalination 2002, 143, 103-113. [CrossRef]

11. Muhammad-Sukki, F.; Munir, A.B.; Ramirez-Iniguez, R.; Abu-Bakar, S.H.; Yasin, S.H.M.; McMeekin, S.G.; Stewart, B.G. Solar photovoltaic in Malaysia: The way forward. Renew. Sustain. Energy Rev. 2012, 16, 5232-5244. [CrossRef]

12. Raturi, A.K. Renewables 2016 Global Status Report; REN21; The University of the South Pacific: Suva, Fiji, 2016; ISBN 978-3-9818107-0-7.

13. Agyekum, E.B.; Amjad, F.; Shah, L.; Velkin, V.I. Optimizing photovoltaic power plant site selection using analytical hierarchy process and density-based clustering-Policy implications for transmission network expansion, Ghana. Sustain. Energy Technol. Assess. 2021, 47, 101521. [CrossRef]

14. Amjad, F.; Agyekum, E.B.; Shah, L.A.; Abbas, A. Site location and allocation decision for onshore wind farms, using spatial multi-criteria analysis and density-based clustering. A techno-economic-environmental assessment, Ghana. Sustain. Energy Technol. Assess. 2021, 47, 101503. [CrossRef]

15. Yaqoob, S.J.; Saleh, A.L.; Motahhir, S.; Agyekum, E.B.; Nayyar, A.; Qureshi, B. Comparative study with practical validation of photovoltaic monocrystalline module for single and double diode models. Sci. Rep. 2021, 11, 19153. [CrossRef]

16. Agyekum, E.B. Techno-economic comparative analysis of solar photovoltaic power systems with and without storage systems in three different climatic regions, Ghana. Sustain. Energy Technol. Assess. 2021, 43, 100906. [CrossRef]

17. Gopi, G.; Arthanareeswaran, G.; Ismail, A.F. Perspective of renewable desalination by using membrane distillation. Chem. Eng. Res. Des. 2019, 144, 520-537. [CrossRef]

18. Datsgerdi, H.R.; Chua, H.T. Thermo-economic analysis of low-grade heat driven multi-effect distillation based desalination processes. Desalination 2018, 448, 36-48. [CrossRef]

19. Zhou, S.; Gong, L.; Liu, X.; Shen, S. Mathematical modeling and performance analysis for multi-e ff ect evaporation/multi-e ff ect evaporation with thermal vapor compression desalination system. Appl. Therm. Eng. 2019, 159, 113759. [CrossRef]

20. Xie, C.; Zhang, L.; Liu, Y.; Lv, Q.; Ruan, G.; Hosseini, S.S. A direct contact type ice generator for seawater freezing desalination using LNG cold energy. Desalination 2018, 435, 293-300. [CrossRef]

21. Tariq, R.; Ahmed, N.; Xamán, J.; Bassam, A. An innovative air saturator for humidi fi cation-dehumidi fi cation desalination application. Appl. Energy 2018, 228, 789-807. [CrossRef]

22. Alwan, N.T.; Shcheklein, S.E.E.; Ali Obed, M.M. Experimental investigation of modified solar still integrated with solar collector. Case Stud. Therm. Eng. 2020, 19, 100614. [CrossRef]

23. Deniz, E. An experimental and theoretical analysis of a vacuum tube solar collector-assisted solar distillation system. Energy Sources Part A Recovery Util. Environ. Eff. 2012, 34, 1637-1645. [CrossRef]

24. Alwan, N.T.; Shcheklein, S.E.; Ali, O.M. Experimental investigations of single-slope solar still integrated with a hollow rotating cylinder. In IOP Conference Series: Materials Science and Engineering; Institute of Physics Publishing: Bristol, UK, 2020 ; Volume 745. [CrossRef]

25. Essa, F.A.; Abdullah, A.S.; Omara, Z.M. Rotating discs solar still: New mechanism of desalination. J. Clean. Prod. 2020, 275, 123200. [CrossRef]

26. Abdullah, A.S.; Alarjani, A.; Abou Al-sood, M.M.; Omara, Z.M.; Kabeel, A.E.; Essa, F.A. Rotating-wick solar still with mended evaporation technics: Experimental approach. Alex. Eng. J. 2019, 58, 1449-1459. [CrossRef]

27. Saxena, A.; Deval, N. A high rated solar water distillation unit for solar homes. J. Eng. 2016, 2016, 7937696. [CrossRef]

28. Ayoub, G.M.; Malaeb, L.; Saikaly, P.E. ScienceDirect Critical variables in the performance of a productivity-enhanced solar still. Sol. Energy 2013, 98, 472-484. [CrossRef]

29. Ayoub, G.M.; Al-Hindi, M.; Malaeb, L. A solar still desalination system with enhanced productivity. Desalin. Water Treat. 2015, 53, 3179-3186. [CrossRef]

30. Ayoub, G.M.; Malaeb, L. Economic feasibility of a solar still desalination system with enhanced productivity. DES 2014, 335, 27-32. [CrossRef]

31. Panchal, H.; Mevada, D.; Sadasivuni, K.K.; Essa, F.A.; Shanmugan, S.; Khalid, M. Experimental and water quality analysis of solar stills with vertical and inclined fins. Groundw. Sustain. Dev. 2020, 11, 100410. [CrossRef] 
32. Panchal, H.; Kumar Sadasivuni, K.; Suresh, M.; Yadav, S.; Brahmbhatt, S. Performance analysis of evacuated tubes coupled solar still with double basin solar still and solid fins. Int. J. Ambient Energy 2020, 41, 1031-1037. [CrossRef]

33. Panchal, H.; Sadasivuni, K.K.; Essa, F.A.; Shanmugan, S.; Sathyamurthy, R. Enhancement of the yield of solar still with the use of solar pond: A review. Heat Transf. 2021, 50, 1392-1409. [CrossRef]

34. Alwan, N.T.; Shcheklein, S.; Ali, O. Investigation of the coefficient of heat transfer and daily cumulative production in a single-slope solar distiller at different water depths. Energy Sources Part A Recovery Util. Environ. Eff. 2020, 43, 1-18. [CrossRef]

35. Alwan, N.T.; Shcheklein, S.E.; Ali, O.M. A practical study of a rectangular basin solar distillation with single slope using paraffin wax (PCM) cells. Int. J. Energy Convers. 2019, 7, 162-170. [CrossRef]

36. Agyekum, E.B.; Praveen Kumar, S.; Alwan, N.T.; Velkin, V.I.; Shcheklein, S.E. Effect of dual surface cooling of solar photovoltaic panel on the efficiency of the module: Experimental investigation. Heliyon 2021, 7, e07920. [CrossRef] [PubMed]

37. Agyekum, E.B.; Praveen Kumar, S.; Alwan, N.T.; Velkin, V.I.; Shcheklein, S.E.; Yaqoob, S.J. Experimental Investigation of the Effect of a Combination of Active and Passive Cooling Mechanism on the Thermal Characteristics and Efficiency of Solar PV Module. Inventions 2021, 6, 63. [CrossRef]

38. Medugu, D.W.; Ndatuwong, L.G. Theoretical analysis of water distillation using solar still. Int. J. Phys. Sci. $2009,4,705-712$.

39. Edition, S. Free convection. Transp. Phenom. Multiph. Flows 2015, 112, 321-338. [CrossRef]

40. Tsilingiris, P.T. Thermophysical and transport properties of humid air at temperature range between 0 and $100{ }^{\circ} \mathrm{C}$. Energy Convers. Manag. 2008, 49, 1098-1110. [CrossRef]

41. Malaeb, L.; Aboughali, K.; Ayoub, G.M. ScienceDirect Modeling of a modified solar still system with enhanced productivity. Sol. Energy 2016, 125, 360-372. [CrossRef]

42. Deceased, J.A.D.; Beckman, W.A. Solar Engineering of Thermal Processes; Solar Energy Laboratory. The University of WisconsinMadison: Madison, WI, USA, 2013.

43. Tharmalingam, S.; Wilkinson, W.L. The coating of Newtonian liquids onto a rotating roll. Chem. Eng. Sci. 1978, 33, 1481-1487. [CrossRef]

44. Kabeel, A.E.; Abdelgaied, M. Improving the performance of solar still by using PCM as a thermal storage medium under Egyptian conditions. Desalination 2016, 383, 22-28. [CrossRef]

45. Tubert-Brohman, I.; Sherman, W.; Repasky, M.; Beuming, T. Improved Docking of Polypeptides with Glide. J. Chem. Inform. Model. 2013, 53, 1689-1699. [CrossRef] [PubMed]

46. Nazari, S.; Safarzadeh, H.; Bahiraei, M. Experimental and analytical investigations of productivity, energy and exergy efficiency of a single slope solar still enhanced with thermoelectric channel and nanofluid. Renew. Energy 2019, 135, 729-744. [CrossRef]

47. Harris Samuel, D.G.; Nagarajan, P.K.; Sathyamurthy, R.; El-Agouz, S.A.; Kannan, E. Improving the yield of fresh water in conventional solar still using low cost energy storage material. Energy Convers. Manag. 2016, 112, 125-134. [CrossRef]

48. Alwan, N.T.; Shcheklein, S.E.; Ali, O.M. Case Studies in Thermal Engineering Evaluation of distilled water quality and production costs from a modified solar still integrated with an outdoor solar water heater. Case Stud. Therm. Eng. 2021, 27, 101216. [CrossRef] 